AperTO - Archivio Istituzionale Open Access dell'Università di Torino

\title{
Protein S-nitrosylation in preconditioning and postconditioning
}

\section{This is a pre print version of the following article:}

Original Citation:

\section{Availability:}

This version is available http://hdl.handle.net/2318/146617

since

Published version:

DOI:10.1177/1535370214522935

Terms of use:

Open Access

Anyone can freely access the full text of works made available as "Open Access". Works made available under a Creative Commons license can be used according to the terms and conditions of said license. Use of all other works requires consent of the right holder (author or publisher) if not exempted from copyright protection by the applicable law. 


\section{(5) \\ UNIVERSITÀ DEGLI STUDI DI TORINO}

This is an author version of the contribution published on:

Questa è la versione dell'autore dell'opera:

[Penna C, Angotti C, Pagliaro P. Protein S-nitrosylation in preconditioning and postconditioning. Exp Biol Med (Maywood). 2014 Mar 25;239(6):647-662. DOI: 10.1177/1535370214522935]

The definitive version is available at:

La versione definitiva è disponibile alla URL:

[http://ebm.sagepub.com/content/239/6.toc] 


\title{
Protein S-Nitrosylation in Preconditioning and Postconditioning
}

\author{
Claudia Penna, Carmelina Angotti and Pasquale Pagliaro
}

University of Torino, Italy

Running title: Protein S-Nitrosylation in Cardioprotection

\section{Correspondence to}

Claudia Penna and Pasquale Pagliaro

Dpt Scienze Cliniche e Biologiche

Regione Gonzole 10, Orbassano (TO)

University of Torino, Italy

e-mail: claudia.penna@unito.it,pasquale.pagliaro@unito.it 


\begin{abstract}
The coronary artery disease is a leading cause of death and morbidity worldwide. This disease has a complex pathophysiology that includes multiple mechanisms. Among these is the oxidative/nitrosative stress. Paradoxically, oxidative/nitrosative signaling plays a major role in cardioprotection against ischemia/reperfusion injury. In this context, the gas transmitter nitric oxide (NO') may act through several mechanisms, such as guanylil cyclase activation and via $S$ nitrosylation (SNO) of proteins. The latter is a covalent modification of a protein cysteine thiol by an NO-group that generates an S-nitrosothiol. Here we report data showing that NO and SNO of proteins play a pivotal role not only in preconditioning, but also in postconditioning cardioprotection.
\end{abstract}

Key Words: Nitration, Nitrosation, Nitrosative signaling, Cardioprotection, Ischemia, Reperfusion. 


\section{Introduction}

Nitric oxide (nitrogen monoxide, $\mathrm{NO}^{\circ}$ ) is synthesized by various nitric oxide synthase (NOS) enzymes or can be produced by other reactions in the biological systems, which are collectively called "non-NOS" processes. The latter includes "non-enzymatic" reactions which are favored by acidic conditions, such as reduction of nitrite to $\mathrm{NO}$, and reactions catalyzed by "non-NOS enzymes", such as cytochrome c, hemoglobin and xanthine oxidoreductase $\mathrm{e}^{1-3}$.

There are three known isoforms of NOSs, besides endothelial NO-synthase (eNOS), cardiac myocytes constitutively express neuronal NO-synthase (nNOS). These two NOSs are $\mathrm{Ca}^{++} /$calmodulin controlled isoenzymes and within the organ and cells they are localized to different microdomains, and are linked to selective signaling that is further impacted by a broad array of key processes in health and disease ${ }^{4,5}$ (see also below). Moreover, the cardiovascular system can express an inducible isoform of NOS (iNOS), which can produce in immune and pathological processes a large amount of $\mathrm{NO}^{*}$ independently of the level of $\mathrm{Ca}^{++}$in the cell. Besides the differences in $\mathrm{Ca}^{++}$ dependency the three NOSs bind calmodulin with different affinities: the general order of affinity is iNOS $>>$ eNOS $>>n N O S$, so that calmodulin can be considered a subunit of iNOS ${ }^{6,7}$. Whether mitochondria also contain a specific NOS contributing to overall NO generation is a matter of debate $^{8}$.

Nitric oxide is considered a free radical with primary regulatory functions in the heart. It is well known that $\mathrm{NO}^{\prime}$ modulates cell function by the activation of soluble guanylyl cyclase (sGC) to form cyclic guanosine monophosphate (cGMP). However, several recent studies suggest that, in addition to activating cGMP-dependent signaling pathways, $\mathrm{NO}^{*}$ generates redox/nitrosative processes, including the posttranslational modification known as protein S-nitrosylation (SNO), which, as we will see in more detail, consists in the covalent attachment of an NO-moiety to a nucleophilic protein sulfhydryl resulting in S-nitrosothiol formation ${ }^{9,10}$ (Fig 1).

The effective targeting of oxidative/nitrosative process in the cardiovascular system critically depends on identifying the primary intracellular regulators. As a matter of fact, both reactive 
oxygen and nitrogen species (ROS/RNS) are localized signaling molecules, at least in physiological conditions $^{9-18}$. In particular, targets of $\mathrm{NO}^{\circ}$ and ROS/RNS are involved in several processes of cardioprotection, including preconditioning (PreC) and postconditioning (PostC) phenomena.

Both PreC and PostC have been demonstrated to significantly attenuate ischemia/reperfusion injury. While PreC can be obtained with one or more brief coronary occlusions of a few minutes (from 2 to 10 min) each before the infarcting ischemia ${ }^{19,20}$, PostC may be performed with one or more brief occlusions of a few seconds (from 5 to $60 \mathrm{~s}$ ) each, starting very early in reperfusion, i.e. a few seconds after the end of the infarcting ischemia ${ }^{21,22}$. These two cardioprotective strategies not only reduce infarct size and affect all form of cell death, but they also attenuate post-ischemic contractile dysfunction, arrhythmias and endothelial dysfunction. Specifically, both PreC and PostC limit endothelial cell dysfunction by increasing eNOS activity and NO bioavailability in neighboring cells $^{23-27}$. The formed NO may be responsible for nitrosative signaling, including nitration and nitrosylation of proteins in these two cardioprotective mechanisms (see below).

From the concepts described above can be inferred that the protein S-nitrosylation is primarily a protective reaction. However, we must keep in mind that S-nitrosylation may also have deleterious effects on cardiovascular function in some specific conditions. For instance, iNOS may be part of pathological processes, such as mitochondrial dysfunction and septic shock ${ }^{28-30}$. In these conditions an excessive S-nitrosylation can have deleterious effects on cardiac and endothelial function (see also below $)^{31,32}$. Although this is true, within the heart iNOS acts as a potent protective enzyme against ischemia/reperfusion injury in the so-called second window of preconditioning (SWOP) ${ }^{33}$. In this setting, it has been reported that atorvastatin may reduce infarct size by increasing the activity of iNOS and cyclooxygenase (COX-2). Of note, it has been demonstrated that COX-2 is activated by iNOS-dependent S-nitrosylation ${ }^{34}$. Actually, the SWOP, which occurs 12-24 hours after the preconditioning stimuli, is primarily mediated by gene induction and protein synthesis. For the mechanisms involved in this window of protection the reader is referred to other excellent reviews on this topic ${ }^{20,35-37}$. 
Our mini-review will focus on acute cardioprotection mechanisms (PreC and PostC), which are primarily mediated by activation of signaling pathways and post-translational modification of proteins. In particular, in this mini-review we focus on the role of S-nitrosylation of proteins in cardioprotection. The distinction of "nitration" from one side and "nitrosation or nitrosylation" from the other side will be first considered. Then the biological conditions that can favor the reaction of S-nitrosylation will be analyzed in the context of preconditioning and postconditioning.

\section{What is protein S-nitrosylation?}

The biology and chemistry of NO is quite complex, for example $a$ ) it plays a plethora of regulatory roles in normal physiology and is involved in several pathophysiological and pathological processes; $b$ ) it can be generated by enzymatic and non-enzymatic processes; and $c$ ) it is involved in several processes of both pro-oxidation and anti-oxidation. In this respect NO is involved in a cornucopia of redox reaction leading to processes of nitration or alternatively to processes of nitrosation/nitrosylation (for reviews see also ${ }^{9,10,38-41}$ ).

Nitrosation or nitrosylation: are they synonyms?

Although nitrosation has been defined as the formation of a covalent bound between a nitrosonium equivalent $\left(\mathrm{NO}^{+}\right)$and a nucleophilic amine, whereas nitrosylation can be defined as the addition of NO without change in the formal charge of the substrate ${ }^{38}$, nitrosation and nitrosylation are often used interchangeably to refer to the same substrate modification. As such, nitrosation/nitrosylation of proteins (i.e. the incorporation of NO-moieties by covalent bonding to various protein groups) is chemically possible not only in the case of cysteine thiols, which leads to the formation of a thionitrite, but also in the case of tryptophan indols, and amines (lysine and N-terminal) ${ }^{39,40}$. Therefore, from a terminology viewpoint, the incorporation of $\mathrm{NO}^{*} / \mathrm{NO}^{+}$moiety to a thiol can be clearly individuated because of the prefix " $S$ ', referring to the incorporation of the moiety to a sulfur atom to form the $S$-NO bond. 
The S-nitrosylating species: nitrogen oxidized species are the most likely candidates for the modification of a reduced thiol. Actually, $\mathrm{NO}_{2}$ and $\mathrm{N}_{2} \mathrm{O}_{3}$ have been considered the typical Snitrosylating species. They are the higher oxidation state (one-electron oxidation) of nitrogen oxides and are formed by the reaction of $\mathrm{NO}^{-}$with molecular oxygen $\left(\mathrm{O}_{2}\right)$ or with peroxynitrite $\left(\mathrm{ONOO}^{-}\right)$, or, alternatively, from acidified nitrite. The reaction of $\mathrm{NO}^{-}$with the superoxide anion $\left(\mathrm{O}_{2}^{-{ }^{-}}\right)$will lead to $\mathrm{ONOO}^{-}$, which, however, may react again with $\mathrm{NO}^{-}$(the so-called secondary reaction) ${ }^{41}$ forming the nitrosylating species $\mathrm{N}_{2} \mathrm{O}_{3}$.

These species reacting with thiol groups of cysteine modify proteins. This post-translational modification can be referred to as S-nitrosation which, in analogy with the phosphorylation of proteins, has become popular as protein S-nitrosylation or protein SNO (or SNO of proteins). From here on, we will prefer either the term "nitrosylation" to refer in general to substrate modification by this kind of reaction or the term "SNO of proteins" to refer to this specific type of reaction observed in biological system, which involves cysteine thiols.

\section{Nitration}

Before to consider the biology of protein S-nitrosylation let's consider nitration to distinguish it from nitrosylation. In fact, nitration must not to be confused with nitrosylation/nitrosation. Nitration involves an electrophilic addition of a nitrotriatomic group, such as an $\mathrm{NO}_{2}{ }^{+}$equivalent (nitronium, an electron acceptor), to an aromatic ring (the site of electron density) ${ }^{38}$. In the biological system, the term nitration refers to the incorporation of the nitrotriatomic group at position 3 of the phenolic ring of tyrosine residues (nitration of tyrosine at its ortho position, which is known as 3-nitration of tyrosine or 3-NT). This protein modification is clearly related to an oxidative stress by the formation of $\mathrm{ONOO}^{-}$, from the reaction of $\mathrm{NO}^{-}$with $\mathrm{O}_{2}^{-}$, in the pathophysiology of the cardiovascular system ${ }^{42-44}$.

However, it must be stressed that nitrosylation and nitration, though they are two different types of reactions, are not mutually exclusive events, but are related in a continuum or Yin-Yang process and can lead in several circumstances to identical final products ${ }^{29}$. Even ONOO $^{-}$can lead to the 
chemistry of the nitrosylation pathway; for instance, it has been suggested that only when the ratio between $\mathrm{NO}^{-}$and $\mathrm{O}_{2}^{-}$is close to $1: 1$ the formation of $\mathrm{ONOO}^{-}$can lead to nitration, whereas a small excess of $\mathrm{NO}^{*}$ will lead to nitrosylation, perhaps via the secondary reaction ${ }^{38}$. For example, it has been suggested that 3 -NT formation is a step of cardioprotective pathways ${ }^{45,46}$. We have recently suggested that after an initial increase of 3-NT, during cardioprotective maneuvers, a subsequent SNO of proteins may prevail in the cardioprotective scenario when NO may be in excess with respect to $\mathrm{O}_{2}^{-47-49}$. We suggest avoiding the use of nitrotyrosilation to indicate tyrosine nitration, since the use of nitrotyrosilation may make confusion with nitrosylation that is a different reaction, as above reported.

\section{Denitrosylation}

Clearly S-nitrosylation is a labile modification, and the levels of nitrosothiols in the biological system are low, due to a rapid turnover. Its transience makes it a typical reaction of nitrosative signaling. Therefore, the concept of denitrosylation has been introduced. It consists in the removal of the nitroso-group and is an important aspect of S-nitrosylation signaling. In fact denitrosylation may limit the amount of protein SNO in order to avoid "excessive" S-nitrosylation, as can occur, for instance, when iNOS is produced in pathological processes comprising nitrosative stress ${ }^{30-32}$. Denitrosylation was firstly considered as a spontaneous and non-regulated process. Recently several non-enzymatic and enzymatic mechanisms of denitrosylation have been described in vitro and in vivo. Non-enzymatic processes include reactions mediated by ascorbate, nucleophilic compounds and transition metal ions that have the possibility to also occur in vivo (for reviews see ${ }^{18,50}$ ). Enzymatic processes may be attributed to denitrosylases, whose actions would be analogous to those of the phosphatases in kinase-signaling. Several denitrosylases may contribute to the compartmentalization of the action of S-nitrosylation of proteins. Although, S-nitrosoglutathione reductase and the thioredoxin system have emerged as the two main enzymatic processes of denitrosylation in vivo, several other enzymes with denitrosylase capability have been observed in vitro and/or in vivo, including carbonyl reductase-1, disulfide isomerase, glutathione peroxidase, 
superoxide dismutase and xanthine oxidase $\mathrm{e}^{47,51-58}$. With respect to thioredoxin system, it has been observed that both cytosolic and mitochondrial isoforms of thioredoxin (Trx1 and Trx2, respectively), as well as the reductases that recharge them, TR1 and TR2, are involved in the process of denitrosylation in a NADPH-dependent manner ${ }^{56,59}$. Yet, the removal of the NO -moiety by glutathione reductase may depend on the transnitrosation of SNO with GSH to form GSNO (Snitrosoglutathione), which will be enzymatically removed. That is, GSH can remove SNO from proteins to generate GSNO which is then converted back to GSH by S-nitrosoglutathione reductase. Similarly thioredoxins can denitrosylate proteins and thioredoxin is then regenerated by thioredoxin reductase. Alternatively, a disulfide bond and a concomitant release of NO-moiety can occur by nucleophilic attack of vicinal protein thiols. The importance of dynamic Snitrosylation/denitrosylation reactions are essential in cardiovascular regulation as demonstrated, for instance, in genetically modified models of increased or decreased activity of S-nitrosoglutathione reductase. In fact in these models the sepsis-induced myocardial depression is positively influenced by denitrosylation ${ }^{32,58-60}$. For reviews on denitrosylation see ${ }^{18,57,60}$.

\section{Biology of S-Nitrosylation}

Nitric oxide is produced by many cell types and has many diverse biological functions. In the cardiovascular system, $\mathrm{NO}^{*}$ is a key regulator of vascular tone $\mathrm{e}^{61,62}$; where it is known to mediate its effects, in part, by binding to the heme moiety of its effector, soluble GC, with the formation of cGMP and subsequent activation of cGMP-dependent signaling. The effects of cGMP are mainly mediated by cGMP-dependent protein kinases, cGMP-regulated ion channels and by cGMPdependent phosphodiesterases ${ }^{63}$ (Fig 1).

There are many additional cGMP-independent actions of $\mathrm{NO}^{\circ}$ that rely on modifications of biomolecules, including the posttranslational modification of proteins, such those that are considered here, i.e., reactions with a reactive cysteine residues to lead to S-nitrosylation or with tyrosine to lead to 3-nitrotirosine formation. 
Clearly, S-nitrosylation is the most important and, perhaps, the most frequent process of nitrosation in ischemia/reperfusion and cardioprotection scenarios. In fact $\mathrm{NO}^{\circ}$ is clearly involved in cardioprotection and within tissues there are many proteins with cysteine/thiol groups, especially within mitochondria membrane. Moreover, because of NO high reactivity the occurrence of SNO in biological systems is quite probable and it is likely that will influence many protein functions. In fact, S-nitrosylation has emerged as an intriguing signaling modality, effectively acting as a reversible molecular switch analogous to phosphorylation.

Importantly, these changes (e.g., S-nitrosylation or tyrosine nitration) have each been shown to occur with physiological and/or pathophysiological levels of NO'. Moreover, these modifications have only been found on a limited number of residues in a subset of proteins in in vivo and in vitro studies, suggesting that the modifications do not occur randomly and, therefore, may constitute a signaling event, akin to phosphorylation ${ }^{9,10,64,65}$. As said, mitochondrial proteins would be preferably S-nitrosylated. In fact, it has been reported that within the hydrophobic environment of biological membranes the reaction between $\mathrm{NO}^{\cdot}$ and $\mathrm{O}_{2}$ is accelerated, thus favoring protein nitrosylation $^{66,67}$; it has also been suggested that the high level of reactive-cysteines in mitochondrial proteins, and the increased stability of $\mathrm{N}_{2} \mathrm{O}_{3}$ in the hydrophobic milieu of the mitochondria, would favor S-nitrosylation ${ }^{9,68}$.

Several studies have shown that nitrosative protein modifications can alter protein function. In particular, there is evidence that S-nitrosylation is reversible, as above described. On the contrary, tyrosine nitration is considered mainly as an irreversible modification that can impact on some signaling pathways associated with formation of $\mathrm{ONOO}^{-}$and $\mathrm{NO}_{2}{ }^{69,70}$. As said, $\mathrm{NO}^{\circ}$ may react with $\mathrm{O}^{-*}$ to form $\mathrm{ONOO}^{-}$and it is widely accepted that enhanced $\mathrm{ONOO}^{-}$formation is cytotoxic via nitrosative stress. Its toxicity is also in line with the irreversibility of the reaction. However, we should keep in mind that physiologic levels of $\mathrm{ONOO}^{-}$may contribute to regulation of normal cellular functions via SNO of mitochondrial and non-mitochondrial proteins ${ }^{69-71}$. Nevertheless, several NO-mediated positive signaling appears to derive from SNO of proteins. In fact, many 
physiological cellular functions in which NO is involved', such as excitation-contraction coupling, G-protein coupled receptor signaling, cardioprotection and regulation of cell death processes (i.e., apoptosis and/or autophagy), require directly protein SNO and/or are mediated by process that follow SNO of proteins (see also below). Although autophagy may be a death process (especially when apoptosis is disabled), it is a pro-survival process that has been seen operative in several mechanisms of cardioprotection ${ }^{72,73}$.

For some authors, SNO of proteins may be considered the typical reaction occurring in redox signaling. In fact a number of S-nitrosylated proteins have been identified in cardiomyocytes ${ }^{57,61-}$ 6365,71,74,75 and cardiomyocyte mitochondria in physiological conditions and in cardioprotection $^{47,65,76}$. Yet SNO can be reversed by intracellular reductants such as glutathione or ascorbate ${ }^{9,77}$, as well as by several enzymes, including $\operatorname{SOD}^{9,52}$ (see also below). Therefore, dynamic S-nitrosylation/de-nitrosylation reactions, which are reminiscent of phosphorylation/dephosphorylation processes, seem essential in cardiovascular regulation ${ }^{58}$.

\section{How is protein SNO protective?}

There is a large and growing list of proteins for which SNO has been shown to alter activity and/or function (see for example ${ }^{9,64,65,78,79}$ ). S-nitrosylation of proteins fulfills the requirements for a signaling post-translational modification: SNO is stimulus mediated and is initiated by processes that favor $\mathrm{NO}^{\bullet}$ formation, either involving or not NOSs. Nitric oxide formed by NOSs or by "nonNOS" processes can directly (or indirectly, see above) lead to SNO of proteins, which can bind to other proteins and can lead to SNO of additional proteins by trans-nitrosylation.

Similarly to other post-translational modifications, SNO can alter the structure, activity, localization and/or stability of proteins, thus altering cell function. Moreover, the nitrosylated cysteine residues result "protected" from irreversible oxidation. Similar to phosphorylation, SNO appears to be not only reversible, but also targeted to specific cysteines. In fact, target proteins may have thousands of cysteine residues, but only a few are reversibly targeted for SNO, as it occurs for ryanodine receptor 
1 (RyR-1) ${ }^{80,81}$. The de-nitrosylation processes are important for the role of SNO, which can put a stop to the signaling, as above described.

SNO has been shown to modify the activity of proteins in virtually all cellular pathways. However, a large number of ion channels seem preferred targets by $\mathrm{SNO}^{80,82-86}$; this is in line with the observation that SNO formation is favored by membrane microdomains and it is especially important in the context of cardioprotection. For instance $\mathrm{Ca}^{++}$channel SNO may reduce calcium overload in I/R (see also below).

Although there are no doubts that S-nitrosylation modifies protein and cell function, the protective effects of these modifications can be gleaned from specific modifications only. For example, protein kinase $\mathrm{B}(\mathrm{Akt})$ is a kinase that when phosphorylated plays an important role in signaling cardioprotection and PTEN (phosphatase and tensin homologue deleted on Chromosome 10) is a phosphatase that dephosphorylates Akt. Both Akt and PTEN have been reported to be subjected to process of SNO. While SNO of Akt prevents the formation of a disulfide bond and attenuates the activity of the enzyme ${ }^{87}$, SNO of PTEN results in its ubiquitination and degradation, thus limiting Akt dephosphorylation $^{88}$. These modifications may be a sort of brake booster, so that Akt activity is permitted, but its exaggerated activation is avoided. In fact prolonged/exaggerated Akt activation has been proposed to be deleterious ${ }^{89}$.

As above stated, SNO has also been suggested to shield thiol groups from irreversible oxidation. In fact, there are data suggesting that S-nitrosylated thiols are protected from irreversible oxidation ${ }^{90-92}$ and this may play a very important role in cardioprotection ${ }^{93,94}$. Redox stress and redox signaling are very important in the genesis of cardiac injury and cardioprotection, respectively ${ }^{10,95}$. Moreover, SNO can also favor other redox modifications, such as disulfide bond formation or glutathiolation that may also regulate function. For example, a disulfide bond between the subunits of protein kinase A (PKA) is formed after treatment with nitrocysteine, an NO donor, thus leading to PKA $\operatorname{activation}^{96}$, which has been also involved in cardioprotection ${ }^{97-99}$. Moreover S-nitrosylation, by enhancing S-glutathiolation of aldose reductase or mitochondrial complex II increases the activity 
of these enzymes ${ }^{100,101}$. Therefore S-glutathiolation favors the reduction of aldehydes and the electron transfer, respectively. Interestingly, S-glutathiolation of both complex II and aldose reductase is decreased during reperfusion following ischemia ${ }^{100,101}$; it might be interesting to determine whether cardioprotective maneuvers reverse the loss of S-glutathiolation in reperfusion.

\section{Preconditioning and Postconditioning}

As above stated, PreC and PostC are two cardioprotective strategies against ischemia/reperfusion injury.

Post-ischemic reperfusion may result in exaggerated ROS generation, $\mathrm{Ca}^{++}$overload, and reduced availability of NO. These modifications together to swift $\mathrm{pH}$ recovery may favor prolonged opening of mitochondrial permeability transition pore (mPTP), and other processes contributing to cell death, myocardial infarction, stunning (a transient post-ischemic contractile dysfunction), and arrhythmias (for reviews see $26,102-104)$.

Ischemic preconditioning can be obtained with brief periods (a few minutes) of intermittent ischemia and reperfusion. These maneuvers trigger two periods of cardioprotection: one immediately after the preconditioning maneuvers that elapse two-three hours (early preconditioning also known as first window of protection) and a second period of protection (SWOP, also known as late preconditioning) that starts 12-24 hours after the preconditioning maneuvers and elapse 48-72 hours $^{22,35-37,105}$. Here we consider the first window of protection, which is applied immediately before the infarcting ischemia and exerts the most potent protection against infarct size. Recent data suggest that early preconditioning cardioprotection is also operative during reperfusion (i.e., in the post-ischemic phase) and limits much of the damage due to ischemia and to reperfusion ${ }^{106-109}$ (see also below).

Postconditioning can be defined as brief (a few seconds) intermittent cycles of reperfusion alternating with coronary re-occlusion applied immediately after the infarcting ischemic event. It has been shown to reduce ischemia/reperfusion damage, in some cases equivalent to that observed with preconditioning. 
Either pre- or post-conditioning phenomena can be triggered by pharmacological interventions, including exogenous NO-donors; namely pharmacological PreC or pharmacological PostC ${ }^{110-115}$. After the discovery of $\mathrm{PreC}$ and PostC phenomena, reperfusion injury has been appreciated as a reality from which protection is feasible, especially with PostC, which is under the control of physicians. Some potentially cooperative protective signaling cascades are recruited by both preand postconditioning, namely the RISK (Reperfusion Injury Salvage Kinase), the SAFE (Survival Activating Factor Enhancement) and the cGMP/protein kinase G (PKG) pathways (Fig 2; these pathways have been described in several recent reviews, for example $27,116-122)$. In brief, several extracellular factors produced endogenously (e.g., adenosine, bradykinin, opioids, etc) bind to cell surface receptors promoting the activation of kinase signaling pathways. The extent of interaction between different pathways and the precise sequence of elements in these pathways are unclear. Nevertheless, a pivotal role has been attributed to the activation of phosphatidyl inositol 3 kinase $(\mathrm{PI} 3 \mathrm{~K}) / \mathrm{Akt}$ and p42/p44 extracellular signal-regulated kinase (ERKs) ${ }^{116-118}$. This pathway, known as the RISK pathway, leads to the inhibition of mPTP opening at reperfusion, via downstream components of the cascade which include the inhibition of glycogen synthase kinase $3 \beta$ (GSK3ß). A pivotal role is also played by NOS and NO . Although the extent to which cGMP/PKG pathway contributes to protection is not clearly established at the present, several studies support the involvement of $\mathrm{NO} / \mathrm{cGMP} / \mathrm{PKG}$ activation in cardioprotection via the attenuation of $\mathrm{Ca}^{++}$overload, which may be responsible for mPTP opening in reperfusion ${ }^{117}$. Moreover, it has been suggested that the activation of intra-mitochondrial PKCe may cause opening of the mitochondrial $\mathrm{K}_{\mathrm{ATP}}$ channel $\left(\mathrm{mK}_{\mathrm{ATP}}\right)$, resulting in a slight increase in ROS, which together with $\mathrm{NO}$ may favor SNO formation which, in turn, may favor mPTP inhibition (Fig 2) ${ }^{119}$. An additional pathway, the so-called SAFE pathway, has been proposed to play a role in cardioprotection. The principal components of the SAFE pathway are TNF $\alpha$, the kinase JAK which phosphorylates the transcription factor STAT3 ${ }^{121}$. Besides the nucleus, STAT3 translocates to the mitochondria where it phosphorylates critical 
components conferring cardioprotection (Fig 2). However, the actions of several components of these pathways need to be finally proven.

As said, the cardioprotective signaling pathways are thought to converge on mitochondria, and various mitochondrial proteins have been identified as targets of post-transitional modifications in both pre- and postconditioning. In these protective pathways, phosphorylative/dephosphorylative processes are widely represented. However, cardioprotective modalities of signal transduction also include redox signaling by ROS, S-nitrosylation by NO and derivative, S-sulfhydration by hydrogen sulfide, as well as O-linked-glycosylation with beta-N-acetylglucosamine ${ }^{10,123,124}$. All these modalities can interact and regulate an entire pathway, thus influencing each other. For instance, enzymes can be phosphorylated and nitrosylated in specific and different site(s) with consequent increase or decrease of their specific activity. For example, ERKs may be Snitrosylated, thus inhibiting its phosphorylation and activation ${ }^{125}$. Another protein that may undergo NO-mediated S-nitrosylation and phosphorylation is the regulator protein phospholamban, which is involved in the control of cardiac contractility and protection ${ }^{9,126,127}$.

Both pre and post-conditioning may be triggered by endogenous and exogenous $\mathrm{NO}^{9,21,26,27,128}$. The relative importance of classical cGMP/PKG pathway and non-classical processes, such as nitrosylation are under intense investigation.

There are several lines of evidence that $S$-nitrosylation of critical proteins plays a pivotal role in cardioprotection by preconditioning ${ }^{34,129-132}$ (see also below). Whether S-nitrosylation is involved in cardioprotection by PostC is going to be clarified in recent years (see also below). In fact, a PubMed search for the words "nitric oxide and preconditioning" gives out thousands articles, whereas a search for the words "nitric oxide and postconditioning" returns hundreds of items. Moreover, a PubMed search for the words "S-nitrosylation and cardioprotection" gives out sixteen items ${ }^{9,34,47,64,65,129-140}$, six of which ${ }^{34,64,129,130,134,137}$ are found also with the words "S-nitrosylation and preconditioning" that gives out in total seventeen references ${ }^{19,34,64,129-132,134,137-148}$. However, four items only are found with the words "S-nitrosylation and postconditioning",10,47,141,149. 
Nevertheless, with a more accurate search we could found few other articles that discuss the role of SNO of proteins in postconditioning. Some of these studies used NO-donors in reperfusion (pharmacological PostC) as protective agents and analyzed the role of protein $\mathrm{SNO}^{28,46,150-153}$. Intriguingly, in a recent Editorial by R. Schulz and P. Ferdinandy ${ }^{144}$, which was written as a comment to an interesting article of Sun $e t a l^{154}$, the authors wonder whether or not "nitric oxide signaling differ in pre- and post-conditioning" and in particular they wonder whether "Snitrosylation is involved in postconditioning's protection". Below we will see that S-nitrosylation is involved in both ischemic and pharmacological postconditioning.

\section{Protein S-nitrosylation in preconditioning}

Several reports have shown that PreC maneuvers induce NO production by activation of NOSs. While the iNOS is involved in the second window of protection ${ }^{36,37}$, both constitutive isoforms of NOS, namely eNOS and nNOS, are implicated in the first window of protection ${ }^{99,155,156}$. Nevertheless, inhibition of NOS not always abolishes the cardioprotection induced by PreC ${ }^{156-159}$. Therefore the "non-NOS" production of NO" may also play a role in PreC scenario ${ }^{160}$. It has been suggested that PreC may provide an environment that favors NO production and SNO of proteins. Among pro-SNO conditions are included favorable ion content, redox equilibrium and acidic $\mathrm{pH}^{129}$. In particular, acidic conditions favor non-enzymatic nitrite reduction to $\mathrm{NO}^{\star}$ and render protein cysteine residues with the $\mathrm{pKa}$ lower than intracellular $\mathrm{pH}$ more sensitive to SNO. However, S-NO bonds are unstable in acidic conditions, so that the observation that $\mathrm{pH}$ is transiently acidic in early reperfusion of protected hearts (see also below) is in line with an important role of protein Snitrosylation for protection against reperfusion injury. In fact it has been suggested that transient acidic $\mathrm{pH}$ in early reperfusion "triggers" SNO formation and the subsequent recovery of $\mathrm{pH}$ may avoid S-NO bond instability ${ }^{47}$. 
The "classical" protection induced by NO" in PreC is dependent, at least in part, by the activation of $\mathrm{GC} / \mathrm{cGMP} / \mathrm{PKG}$, which in turn may lead to the opening of the mKATP channel in cooperation with intra-mitochondrial PKC $\varepsilon^{13,33}$ (Fig 2).

Recently, Sun et al., have reported that the protective effect of $\mathrm{NO}^{\circ}$ is not related primarily to activation of the sGC/cGMP/PKG signaling pathway, but rather through SNO signaling in PreCinduced early cardioprotection (Fig 1) ${ }^{154}$. In fact the infusion of the inhibitor of sGC, $1 \mathrm{H}$ $[1,2,4]$ oxadiazolo[4,3-a]quinoxalin-1-one (ODQ), did not abolish completely the cardioprotection induced by PreC. Intriguingly, hearts treated with ODQ displayed enhanced protection concomitant with a higher SNO level. These results suggest that NO mediated cardioprotection is regulated by SNO of proteins rather than through activation of the sGC/cGMP/PKG signaling ${ }^{154,161}$. With an elegant experimental approach the same group ${ }^{131}$ has demonstrated in isolated heart that caveolin-3associated eNOS/NO trafficking between plasma membrane and mitochondria provides an important signaling pathway regulating SNO of mitochondrial proteins. It seems that the NO /SNO signaling induced by PreC maneuvers is transported to mitochondria starting from the caveolae. In fact the caveolae are important for many signaling pathways and the disruption of caveolae could inhibit protection by blocking a number of signaling pathways ${ }^{162,163}$. This is in line with the observation that blockade of the internalization of signaling molecules associated with G-proteincoupled receptors inhibits cardioprotection afforded by $\operatorname{PreC}^{164}$ and it is in line with the central role of mitochondria in cardioprotection ${ }^{165,166}$. However, as above said, a role for sGC in cardioprotection has been demonstrated several times, including studies which used a specific sGC activator $^{167-169}$. This suggests that both effects (sCG activation and protein SNO) may take place in cardioprotection, with, perhaps, the prevalence of one or the other effect in the different phases of the cardioprotective signaling cascade.

Several nitrosylated proteins have been somehow involved in cardioprotection (Table 1$)^{65 .}$ Here we consider some of them involved in preconditioning only. The action of S-nitrosylation during PreC is important for many enzymes and cellular structures. In fact, SNO induces modification of the 
activity of both metabolic enzymes ${ }^{155}$ and proteins involved in the mechanisms for calcium control $^{171}$, which are particularly important for cardioprotection (Fig 3). In fact, in cardiac cells the levels of $\mathrm{Ca}^{++}$are regulated by different mechanisms, including $\mathrm{Ca}^{++}$handling by trans-membrane calcium channels ${ }^{129,172}$, mitochondrial transporters and sarcoplasmatic components, such as ryanodine receptor 2 (RyR-2) and sarcoplasmatic reticulum pump $\left(\mathrm{SERCA}_{2}\right)^{129,171}$ (Fig 4). The relative contribution of each of these mechanisms to the intracellular $\mathrm{Ca}^{++}$levels is different in preischemic, ischemic and post-ischemic conditions with also gender-based differences (for reviews $\left.\operatorname{see}^{130,173}\right)$.

Similarly to RyR-1 in skeletal muscle ${ }^{175,176}$, RyR-2 in cardiac cells ${ }^{177}$ is endogenously Snitrosylated, suggesting that SNO is a physiological modulator of both skeletal and cardiac cell excitation-contraction coupling. In particular, a number of studies have reported that NO-donor concentration, oxygen tension, membrane potential, the presence of RyR agonists and other sulfhydryl modifying reagents may influence the effect of SNO on RyR activity ${ }^{175-181}$. The majority of studies report an increased $\mathrm{Ca}^{++}$release following SNO of RyR-1 in skeletal muscle, whereas the effect of RyR-2 SNO is less clear in cardiac muscle (question mark in Fig 4). Some evidences suggests that RyR-2 SNO increased $\mathrm{Ca}^{++}$release while other data suggest that RyR-2 SNO reduced $\mathrm{Ca}^{++}$release. In fact, it has been reported that like RyR-1, RyR-2 activity is dependent on oxygen tension. However, unlike RyR-1, RyR-2 was not effectively S-nitrosylated and activated by NOdonor. Yet, RyR-2 was modified and activated by GSNO, ONOO- and HNO (one-electron reduction product of NO $)^{177,179,182,183}$. Ischemic PreC and application of GSNO, HNO and NO donors resulted in cardiac protection against I/R injury and elicited a similar pattern of protein $\mathrm{SNO}^{129,182,184}$. This suggests that S-nitrosylation of protein protects cells from I/R damage. Although it is likely that RyR-2 is modified in the ischemic/reperfused and conditioned hearts, the redox modifications and activity are unclear.

The effects of NO-related activity and cellular thiol redox state on basal L-type calcium current, (ICa,L), have been studied using the patch clamp technique. It has been found that both cGMP- 
dependent and redox-dependent mechanisms (i.e., S-nitrosylation and/or thiol oxidation) are involved in inhibition and stimulation of $\mathrm{ICa}, \mathrm{L}$, respectively. These findings suggest that direct redox modulation of sarcolemmal L-type calcium channels is a physiologically relevant mechanism for modulation of cardiac mechanical function ${ }^{185}$. However, it has been reported that nitrosothiols induce inhibition of L-type calcium channels (Fig 4), and that this inhibition involves both a reduction of the open probability of the single channel and a reduction of the conductance ${ }^{129,172,186,187}$. Importantly, it has been reported that $\alpha 1$-subunits of the $\mathrm{Ca}^{++}$channels are constitutively S-nitrosylated in the mouse heart. Yet, their nitrosylation increases after ischemia leading to the inhibition of the channels in female hearts only, supporting gender differences in post-ischemic $\mathrm{Ca}^{++-}$overload in cardiac cells, which can be at the basis of smaller infarct size in females $^{84}$. In particular, the S-nitrosylation of $\alpha 1$ subunit is increased during PreC maneuvers. Moreover, the pharmacological PreC with GSNO (a nitric oxide donor) reduces the damage after $\mathrm{I} / \mathrm{R}$ and is associated with a decreased $\mathrm{Ca}^{++}$entry through L-type calcium channels ${ }^{129}$. Similarly, the pharmacological preconditioning induced by PAF (platelet activating factor) leads to the Snitrosylation of calcium channels and consequent reduction of post-ischemic $\mathrm{Ca}^{++}$overload ${ }^{132,188}$. Another important protein that is S-nitrosylated is the SERCA 2 pump ${ }^{129}$, which is also involved in calcium handling and is associated to infarct size reduction and improved cardiac function following myocardial ischemia ${ }^{129,189}$. In fact, during ischemia and early reperfusion, SERCA $_{2}$ pump activity may reduce calcium overload, also improving diastolic cardiac relaxation ${ }^{190}$. Importantly, PreC and GSNO pretreatment (concentration-dependently) increase SERCA 2 activity. Moreover, it has been suggested that $\mathrm{SERCA}_{2}$ pump SNO is responsible for the increased activity, which is associated to a reduced open probability of mPTP (Figs 2, 3 and 4). In fact, as said, the pore opening depends on calcium levels.

Besides single protein S-nitrosylation, such as $\mathrm{Ca}^{++}$channels and $\mathrm{SERCA}_{2}$, multiple S-nitrosylated proteins have been shown by proteomic studies after PreC ${ }^{64,191}$. Many of these proteins have been found within mitochondria. In fact, PreC increases the S-nitrosylation of different proteins 
responsible for mitochondrial metabolism (e.g. alpha-ketoglutarate dehydrogenase, glycogen phosphorylase, aconitase, ), with modification and preservation of their activity ${ }^{65,138,192}$. During PreC was also observed the inhibition of $\mathrm{F}_{0} \mathrm{~F}_{1}$-ATPase by S-nitrosylation, with consequent reduction of ATP consumption by reserve mode of $\mathrm{F}_{0} \mathrm{~F}_{1}$-ATPase, which typically occurs in ischemic conditions $^{138,192}$ (Fig 3). The inhibition of $\mathrm{F}_{0} \mathrm{~F}_{1}$-ATPase preserves ATP levels and reduces the mitochondrial membrane potential, thereby reducing the driving force for calcium uptake into the mitochondrial matrix, thus increasing tolerance to ischemia ${ }^{160}$. Another important component that is subjected to S-nitrosylation during PreC, is the mitochondrial respiratory complex I, which is reversible inhibited when nitrosylated ${ }^{151}$. An irreversible inhibition of this complex can occur when it is subjected to nitrosation by $\mathrm{ONOO}^{-9,193}$.

As stated above, an important effector of cardioprotection is the inhibition of mPTP opening $^{25,165,194}$. In fact this pore is regulated by ROS, calcium and mitochondrial membrane potential, which are regulated by SNO of proteins. Not only the decrease of calcium loading by increased reuptake by $\mathrm{SNO}$ of $\mathrm{SERCA}_{2}$, but also the S-nitrosylation of $\mathrm{F}_{0} \mathrm{~F}_{1}$-ATPase reduces indirectly the opening of mPTP, which reduces the breakdown of glycolytic ATP and the acceleration of the fall in the mitochondrial membrane potential. Moreover, S-nitrosylation of CyPD (cyclophillin D) ${ }^{195}$ and/or of VDAC (voltage dependent anion channel) ${ }^{149}$, two putative components of mPTP rich in thiol groups, may occur in cardioprotection.

Recently Kohr et $a l^{134}$ using two different methods to measure protein oxidation have shown that preconditioning leads to SNO of many proteins and that a large majority of these proteins are protected from oxidation.

All together, these data support the view that S-nitrosylation of mitochondrial proteins serves as an important mechanism of preconditioning cardioprotection.

\section{Is S-nitrosylation important for postconditioning's protection?}


Several lines of evidence and experimental data suggest that S-nitrosylation is involved in postconditioning's protection.

As stated, $\mathrm{NO}^{\circ}$ can derive from enzymatic and non-enzymatic processes and the latter are favored by acidosis ${ }^{1,196}$, a condition that is of paramount importance in inducing postconditioning's cardioprotection $^{128}$. As reported by several authors, PostC attenuates endothelial cell dysfunction by increasing eNOS activity and NO bioavailability ${ }^{21,197}$. Activation of PKC plays a central role in cardioprotection $^{26}$ and postconditioning ${ }^{198,199}$, and, importantly, PKC activation via redox-sensible S-nitrosylation process has been also suggested ${ }^{91}$. We should recall that PKC is also a target of PKG, thus further supporting a protective role of sGC/cGMP/PKG signaling. Whether PKG may target directly or indirectly PKC is a matter of debate ${ }^{13,149,200,201}$.

We have found that PostC discretely changes the activity of antioxidant enzymes in early reperfusion, slightly decreasing SOD and increasing catalase activity ${ }^{47}$. Since SOD may be a denitrosylating enzyme ${ }^{9}$, these effects may favor S-nitrosylation thus reducing injury due to oxidativestress (Fig 5).

The instantaneous redox state and ultrastructural accessibility of cysteine residue(s) under lowoxygen tension, such as hypoxia, ischemia and postconditioning intermittent ischemia/reperfusion may determine whether a particular thiol in a given protein is subjected to S-nitrosylation ${ }^{202}$.

We have shown in rat hearts that after 7-min of reperfusion ischemic PostC induces a reduction in 3-nitrotyrosine levels and an increase in S-nitrosylation of proteins, which persist for at least the 120 min of reperfusion ${ }^{47}$. The reduced levels of 3-nitrotyrosine in PostC have also been observed by Inserte et $a l^{49}$. Very recently, we have shown that protein S-nitrosylation occurs mainly in mitochondria either after ischemic PostC or pharmacological PostC induced by Diazoxide ${ }^{149}$ (a drug supposed to promote ROS-signaling through actions on mKATP channels and connexin 43) $25,203-205$. In another study, addition of a mitochondria-targeted SNO at the start of reperfusion (i.e., pharmacological PostC) has also been found to be cardioprotective ${ }^{206}$. The $\mathrm{NO}^{-}$-donor used in this study is the so-called MitoSNO, which comprises the well known NO ${ }^{\circ}$-donor SNAP (S-nitroso-N- 
acetylpenicillamine) conjugated to a triphenylphosphonium (TPP) moiety. The lipophilic TPP allows MitoSNO to pass rapidly through membranes driven by the membrane potential and therefore to accumulate several-hundred-fold within the mitochondria, where it generates $\mathrm{NO}^{\circ}$ and S-nitrosylates thiol proteins ${ }^{206}$. The nitrosylation of proteins by MitoSNO and other donors has been confirmed by other authors both in basal conditions and in the context of postconditioning cardioprotection $^{206,207}$. Intriguingly, in a recent study Methner et al ${ }^{150}$ have reported that the most abundant isoforms of PKG (PKGI) within cardiomyocyte is involved in cardioprotection against ischemia/reperfusion injury. However, after cardiomyocyte-specific ablation of the PKGI gene in the mouse, these authors have shown that it is possible to protect the hearts with several interventions, including PostC with intermittent ischemia or with the NO donor MitoSNO, via Snitrosylation of mitochondrial proteins. Therefore, the authors concluded that PostC may afford protection either by-passing PKGI or by acting independently or downstream of it. Using this conditional knockout approach to inactivate PKGI the authors suggested differences between cGMP/PKGI pathway in myocytes and other cardiac cell types during ischemic PostC's protection in vivo. However they cannot rule out that the exogenous and endogenous $\mathrm{NO}^{\circ}$ may act to protect the heart from reperfusion injury in a manner that depends on PKG in other cardiac cell types. In fact, PKG has been involved in PostC protection in different models by several authors ${ }^{49,150,208,209}$. Therefore, for the reasons above reported, NO appears to be an important mediator in PostC and both cGMP/PKG-dependent signaling ${ }^{49,150,208}$ and mitochondrial protein $S$-nitrosylation ${ }^{47,149}$ play a pivotal role in postconditioning's cardioprotection (Fig 5).

Our recent finding that PostC with Diazoxide enhances S-nitrosylation, supports the idea that an appropriate redox environment is necessary for SNO-mediated cardioprotection ${ }^{25,149,203-205}$. Intriguingly, Diazoxide enhances protein SNO also in the absence of ischemia, thus suggesting that part of the preconditioning effect induced by this drug may be attributed to the S-nitrosylation of critical proteins. 
During the first minutes of reperfusion usually a typical large burst of ROS occurs in naif (not protected) hearts. The ROS burst is well documented to result in the irreversible oxidation of a number of important proteins. These proteins are irreversibly modified and need to be degraded and re-synthesized to regain normal function, otherwise myocardial injury occurs. Because SNO is a transient readily reversed modification, the shielding effect of SNO must be timing. This could be of paramount importance during PostC maneuvers. In fact the ROS burst is attenuated by PostC maneuvers and SNO occurring during PostC may shield modified cysteines from more irreversible states of oxidation till the burst of ROS vanishes. This point of view is in line with the experimental evidence that a delay in performing PostC maneuvers results in a loss of protection ${ }^{22,94,210}$. It has been find that protein nitration may be beneficial ${ }^{45,46}$ or deleterious ${ }^{49,211,212}$ in PostC. We have proposed that protein nitration may be a transient effect of PostC, which is suddenly followed by the prevalence of protein S-nitrosylation ${ }^{47}$.

Further studies are needed to fully explore the role of protein SNO in both cardiomyocytes and in non-myocyte cell populations as well as the signaling pathways involved in cardioprotection. In particular, it is necessary to individuate the specific S-nitrosylated proteins, their main localization and the role they have in PostC cardioprotection.

\section{Conclusions}

Coronary heart disease is a major cause of death and morbidity worldwide. Nitrosative and oxidative/reductive stress is among the major contributors to its varied pathophysiology. New insights into the sources of oxidative/nitrosative stress, its compartmentalized targets, and the understanding of endogenous and exogenous modulators "designed" to control this stress may pave the road for novel approaches and therapies. These can go further to oxidant-scavenging therapies for cardiovascular disease that have been disappointing to date. With no doubt SNO is gaining much attention in the "cardiovascular community" and the understanding of its precise role may open new perspectives in the field of ischemic heart disease. As evidenced in this minireview the 
nitrosative/oxidative signaling is a major player in the triggering of cardioprotection and among the plethora of reaction mediated by this signaling the covalent attachment of an NO-moiety to a nucleophilic protein sulfhydryl resulting in SNO is a fundamental step for cardioprotection. Here, we have highlighted experimental evidences of SNO contribution in both pre and postconditioning and have considered the possible cooperation between nitration and nitrosylation in inducing postconditioning protection. 
Statement of Author Contributions and Acknowledgments:

\section{Author Contributions:}

All authors participated in the design of the Minireview and selection of the articles to be quoted;

$\mathrm{CP}$ and PP wrote the first draft of the manuscript, and CA made the figures and legends. All the authors have read and critically suggested revisions before the submission.

\section{Acknowledgements}

The authors thank Prof Donatella Gattullo and Dr Daniele Mancardi for invaluable suggestions.

'The Authors declare that there is no conflict of interest'.

\section{Funding:}

The authors for the writing of this article received no specific grant from any funding agency in the public, commercial, or not-for-profit sectors. The researches of the authors were supported by funding from the Italian Ministry of the University and Research (MIUR) "Progetti di Rilevanza Nazionale" [PRIN, 2008, CP] and "Fondi per la Ricerca Locale" [Unito ex-60\%, PP, CP] . 


\section{References}

1. Zweier JL, Samouilov A, Kuppusamy P. Non-enzymatic nitric oxide synthesis in biological systems. Biochim Biophys Acta. 1999;1411:250-62.

2. Zweier JL, Li H, Samouilov A, Liu X. Mechanisms of nitrite reduction to nitric oxide in the heart and vessel wall. Nitric Oxide 2010;22:83-90

3. Trujillo M, Alvarez MN, Peluffo G, Freeman BA, Radi R. Xanthine oxidase-mediated decomposition of S-nitrosothiols. J Biol Chem. 1998;273:7828-34.

4. Lim G, Venetucci L, Eisner DA, Casadei B. Does nitric oxide modulate cardiac ryanodine receptor function? Implications for excitation-contraction coupling. Cardiovasc Res. 2008;77:25664.

5. Zhang YH, Casadei B. Sub-cellular targeting of constitutive NOS in health and disease. J Mol Cell Cardiol. 2012;52:341-50.

6. Stuehr DJ. Mammalian nitric oxide synthases. Biochim Biophys Acta. 1999;1411:217-30

7. Xia C, Misra I, Iyanagi T, Kim JJ. Regulation of interdomain interactions by calmodulin in inducible nitric-oxide synthase. J Biol Chem. 2009;284:30708-17.

8. Zaobornyj T, Ghafourifar P. Strategic localization of heart mitochondrial NOS: a review of the evidence. Am J Physiol Heart Circ Physiol. 2012;303:H1283-93.

9. Sun J, Murphy E. Protein S-nitrosylation and cardioprotection. Circ Res. 2010;106:285-96.

10. Pagliaro P, Moro F, Tullio F, Perrelli MG, Penna C. Cardioprotective pathways during reperfusion: focus on redox signaling and other modalities of cell signaling. Antioxid Redox Signal. 2011;14:833-50.

11. Brady NR, Hamacher-Brady A, Westerhoff HV, Gottlieb RA. A wave of reactive oxygen species (ROS)-induced ROS release in a sea of excitable mitochondria. Antioxid Redox Signal. 2006;8:1651-65.

12. Baines CP. The mitochondrial permeability transition pore as a target of cardioprotective signaling. Am J Physiol Heart Circ Physiol. 2007;293:H903-4. 
13. Costa AD, Garlid KD. Intramitochondrial signaling: interactions among mitoKATP, PKCepsilon, ROS, and MPT. Am J Physiol Heart Circ Physiol. 2008;295:H874-82.

14. Dost T, Cohen MV, Downey JM. Redox signaling triggers protection during the reperfusion rather than the ischemic phase of preconditioning. Basic Res Cardiol. 2008;103:378-84.

15. Brown DI, Griendling KK. Nox proteins in signal transduction. Free Radic Biol Med. 2009;47:1239-53.

16. Chen K, Craige SE, Keaney JF, Jr. Downstream targets and intracellular compartmentalization in Nox signaling. Antioxid Redox Signal. 2009;11:2467-80.

17. Garlid AO, Jaburek M, Jacobs JP, Garlid KD. Mitochondrial Reactive Oxygen Species Which ROS Signals Cardioprotection? Am J Physiol Heart Circ Physiol. 2013;305:H960-8.

18. Martinez-Ruiz A, Araujo IM, Izquierdo-Alvarez A, Hernansanz-Agustin P, Lamas S, Serrador JM. Specificity in S-Nitrosylation: A Short-Range Mechanism for NO Signaling? Antioxid Redox Signal. 2013;doi:10.1089/ars.2012.5066

19. Murry CE, Jennings RB, Reimer KA. Preconditioning with ischemia: a delay of lethal cell injury in ischemic myocardium. Circulation 1986;74:1124-36.

20. Pagliaro P, Gattullo D, Rastaldo R, Losano G. Ischemic preconditioning: from the first to the second window of protection. Life Sci. 2001;69:1-15.

21. Zhao ZQ, Corvera JS, Halkos ME, Kerendi F, Wang NP, Guyton RA, Vinten-Johansen J. Inhibition of myocardial injury by ischemic postconditioning during reperfusion: comparison with ischemic preconditioning. Am J Physiol Heart Circ Physiol. 2003;285:H579-88.

22. Skyschally A, Van Caster P, Iliodromitis EK, Schulz R, Kremastinos DT, Heusch G. Ischemic postconditioning: experimental models and protocol algorithms. Basic Res Cardiol. 2009;104:469-83.

23. Yellon DM, Downey JM. Preconditioning the myocardium: from cellular physiology to clinical cardiology. Physiol Rev. 2003;83:1113-51. 
24. Schulz R, Kelm M, Heusch G. Nitric oxide in myocardial ischemia/reperfusion injury. Cardiovasc Res. 2004;61:402-13.

25. Boengler K, Heusch G, Schulz R. Mitochondria in postconditioning. Antioxid Redox Signal. 2011;14:863-80.

26. Cohen MV, Downey JM. Ischemic postconditioning: from receptor to end-effector. Antioxid Redox Signal. 2011;14:821-31.

27. Hausenloy DJ, Lecour S, Yellon DM. Reperfusion injury salvage kinase and survivor activating factor enhancement prosurvival signaling pathways in ischemic postconditioning: two sides of the same coin. Antioxid Redox Signal. 2011;14:893-907.

28. Nakamura T, Lipton SA. S-nitrosylation of critical protein thiols mediates protein misfolding and mitochondrial dysfunction in neurodegenerative diseases. Antioxid Redox Signal. 2011;14:1479-92.

29. Brown GC, Borutaite V. Inhibition of mitochondrial respiratory complex I by nitric oxide, peroxynitrite and S-nitrosothiols. Biochim Biophys Acta. 2004;1658:44-9.

30. Titheradge MA. Nitric oxide in septic shock. Biochim Biophys Acta. 1999;1411:437-55.

31. Santhanam L, Lim HK, Lim HK, Miriel V, Brown T, Patel M, Balanson S, Ryoo S, Anderson M, Irani K, Khanday F, Di Costanzo L, Nyhan D, Hare JM, Christianson DW, Rivers R, Shoukas A, Berkowitz DE. Inducible NO synthase dependent S-nitrosylation and activation of arginase1 contribute to age-related endothelial dysfunction. Circ Res. 2007;101:692-702.

32. Sips PY, Irie T, Zou L, Shinozaki S, Sakai M, Shimizu N, Nguyen R, Stamler JS, Chao W, Kaneki M, Ichinose F. Reduction of cardiomyocyte S-nitrosylation by S-nitrosoglutathione reductase protects against sepsis-induced myocardial depression. Am J Physiol Heart Circ Physiol. 2013;304:H1134-46.

33. Jones SP, Bolli R. The ubiquitous role of nitric oxide in cardioprotection. J Mol Cell Cardiol. 2006;40:16-23. 
34. Atar S, Ye Y, Lin Y, Freeberg SY, Nishi SP, Rosanio S, Huang MH, Uretsky BF, PerezPolo JR, Birnbaum Y. Atorvastatin-induced cardioprotection is mediated by increasing inducible nitric oxide synthase and consequent S-nitrosylation of cyclooxygenase-2. Am J Physiol Heart Circ Physiol. 2006;290:H1960-8.

35. Hausenloy DJ, Yellon DM. The second window of preconditioning (SWOP) where are we now? Cardiovasc Drugs Ther. 2010;24:235-54.

36. Bolli R. The late phase of preconditioning. Circ Res. 2000;87:972-83.

37. Bolli R, Dawn B, Tang XL, Qiu Y, Ping P, Xuan YT, Jones WK, Takano H, Guo Y, Zhang J. The nitric oxide hypothesis of late preconditioning. Basic Res Cardiol. 1998;93:325-38.

38. Espey MG, Miranda KM, Thomas DD, Xavier S, Citrin D, Vitek MP, Wink DA. A chemical perspective on the interplay between NO, reactive oxygen species, and reactive nitrogen oxide species. Ann N Y Acad Sci. 2002;962:195-206.

39. Simon DI, Mullins ME, Jia L, Gaston B, Singel DJ, Stamler JS. Polynitrosylated proteins: Characterization, bioactivity, and functional consequences. Proc Natl Acad Sci USA. 1996;93:4736-41.

40. Zhang YY, Xu AM, Nomen M, Walsh M, Keaney JF Jr, Loscalzo J. Nitrosation of tryptophan residue(s) in serum albumin and model dipeptides. Biochemical characterization and bioactivity. J Biol Chem. 1996;271:14271-9.

41. Wink DA, Darbyshire JF, Nims RW, Saavedra JE, Ford PC. Reactions of the bioregulatory agent nitric oxide in oxygenated aqueous media: determination of the kinetics for oxidation and nitrosation by intermediates generated in the NO/O2 reaction. Chem Res Toxicol. 1993;6:23-7.

42. Zou M, Martin C, Ullrich V. Tyrosine nitration as a mechanism of selective inactivation of prostacyclin synthase by peroxynitrite. Biol Chem. 1997;378:707-13.

43. Turko IV, Murad F. Protein nitration in cardiovascular diseases. Pharmacol Rev. 2002;54:619-34. 
44. Ischiropoulos H. Biological selectivity and functional aspects of protein tyrosine nitration. Biochem Biophys Res Commun. 2003;305:776-83.

45. Kupai K, Csonka C, Fekete V, Odendaal L, van Rooyen J,Marais de W, Csont T, Ferdinandy P. Cholesterol diet induced hyperlipidemia impairs the cardioprotective effect of postconditioning: Role of peroxynitrite. Am J Physiol Heart Circ Physiol. 2009;297:H1729-35.

46. Li J, Loukili N, Rosenblatt-Velin N, Pacher P, Feihl F, Waeber B, Liaudet L. Peroxynitrite is a key mediator of the cardioprotection afforded by ischemic postconditioning in vivo. PLoS One. 2013;8:e70.

47. Penna C, Perrelli MG, Tullio F, Moro F, Parisella ML, Merlino A, Pagliaro P. Post-ischemic early acidosis in cardiac postconditioning modifies the activity of antioxidant enzymes, reduces nitration, and favors protein S-nitrosylation. Pflugers Arch. 2011;462:219-33.

48. Yang YY, Lee KC, Huang YT, Wang YW, Hou MC, Lee FY, Lin HC, Lee SD. Effects of $\mathrm{N}$-acetylcysteine administration in hepatic microcirculation of rats with biliary cirrhosis. J Hepatol. 2008;49:25-33.

49. Inserte J, Hernando V, Vilardosa Ú, Abad E, Poncelas-Nozal M, Garcia-Dorado D. Activation of cGMP/protein kinase G pathway in postconditioned myocardium depends on reduced oxidative stress and preserved endothelial nitric oxide synthase coupling. J Am Heart Assoc. 2013;2:e05975.

50. Stamler JS, Toone EJ. The decomposition of thionitrites. Curr Opin Chem Biol. 2002;6:779-85.

51. Hou Y, Guo Z, Li J, Wang PG. Seleno compounds and glutathione peroxidase catalyzed decomposition of S-nitrosothiols. Biochem Biophys Res Commun. 1996;228:88-93.

52. Grisham MB. Effect of superoxide dismutase on the stability of S-nitrosothiols. Arch Biochem Biophys. 1999;361:323-30.

53. Jourd'heuil D, Laroux FS, Miles AM, Wink DA, Grisham MB. Effect of superoxide dismutase on the stability of S-nitrosothiols. Arch Biochem Biophys. 1999;361:323-30. 
54. Sliskovic I, Raturi A, Mutus B. Characterization of the S-denitrosation activity of protein disulfide isomerase. J Biol Chem. 2005;280:8733-41.

55. Bateman RL, Rauh D, Tavshanjian B, and Shokat KM. Human carbonyl reductase 1 is an Snitrosoglutathione reductase. J Biol Chem. 2008;283:35756-62.

56. Benhar M, Forrester MT, Hess DT, Stamler JS. Regulated protein denitrosylation by cytosolic and mitochondrial thioredoxins. Science. 2008;320:1050-54.

57. Anand P, Stamler JS. Enzymatic mechanisms regulating protein S-nitrosylation: Implications in health and disease. J Mol Med (Berl). 2012;90:233-44.

58. Beigi F, Gonzalez DR, Minhas KM, Sun QA, Foster MW, Khan SA, Treuer AV, Dulce RA, Harrison RW, Saraiva RM, Premer C, Schulman IH, Stamler JS, Hare JM. Dynamic denitrosylation via S-nitrosoglutathione reductase regulates cardiovascular function. Proc Natl Acad Sc. USA. 2012;109:4314-19.

59. Sengupta R, Ryter SW, Zuckerbraun BS, Tzeng E, Billiar TR, Stoyanovsky DA. Thioredoxin catalyzes the denitrosation of low-molecular mass and protein S-nitrosothiols. Biochemistry. 2007;46:8472-83.

60. Benhar M, Forrester MT, Stamler JS. Protein denitrosylation: Enzymatic mechanisms and cellular functions. Nat Rev Mol Cell Biol. 2009;10:721-32.

61. Melikian N, Seddon MD, Casadei B, Chowienczyk PJ, Shah AM. Neuronal nitric oxide synthase and human vascular regulation. Trends Cardiovasc Med. 2009;19:256-62.

62. Pagliaro P. Differential biological effects of products of nitric oxide (NO) synthase: it is not enough to say NO. Life Sci. 2003;73:2137-49.

63. Hofmann F, Feil R, Kleppisch T, Schlossmann J. Function of cGMP-dependent protein kinases as revealed by gene deletion. Physiol Rev. 2006;86:1-23.

64. Foster DB, Van Eyk JE, Marbán E, O'Rourke B. Redox signaling and protein phosphorylation in mitochondria: progress and prospects. J Bioenerg Biomembr. 2009;41:159-68. 
65. Murphy E, Kohr M, Sun J, Nguyen T, Steenbergen C. S-nitrosylation: a radical way to protect the heart. J Mol Cell Cardiol. 2012;52:568-77.

66. Liu X, Miller MJS, Joshi MS, Thomas DD, Lancaster JR. Accelerated reaction of nitric oxide with $\mathrm{O} 2$ within the hydrophobic interior of biological membranes. Proc Natl Acad Sci U S A. 1998;95:2175-79.

67. Nedospasov A, Rafikov R, Beda N, Nudler E. An autocatalytic mechanism of protein nitrosylation. Proc Natl Acad Sci U S A. 2000;97:13543-48.

68. Burwell LS, Brookes PS. Mitochondria as a target for the cardioprotective effects of nitric oxide in ischemia-reperfusion injury. Antioxid Redox Signal. 2008;10:579-99.

69. Pacher P, Beckman JS, Liaudet L. Nitric oxide and peroxynitrite in health and disease. Physiol Rev. 2007;87:315-424.

70. Ischiropoulos H. Protein tyrosine nitration-An update. Arch Biochem Biophys. 2009;484:117-21.

71. Ferdinandy P, Schulz R. Nitric oxide, superoxide, and peroxynitrite in myocardial ischaemia-reperfusion injury and preconditioning. Br J Pharmacol. 2003;138:532-43.

72. Edinger AL, Thompson CB. Death by design: apoptosis, necrosis and autophagy. Curr Opin Cell Biol. 2004;16:663-9.

73. Gottlieb RA, Finley KD, Mentzer RM Jr. Cardioprotection requires taking out the trash. Basic Res Cardiol. 2009;104:169-80.

74. Giricz Z, Görbe A, Pipis J, Burley DS, Ferdinandy P, Baxter GF. Hyperlipidaemia induced by a high-cholesterol diet leads to the deterioration of guanosine-3',5'-cyclic monophosphate/protein kinase G-dependent cardioprotection in rats. Br J Pharmacol. 2009;158:1495-502.

75. Kohr MJ, Aponte AM, Sun J, Wang G, Murphy E, Gucek M, Steenbergen C. Characterization of potential S-nitrosylation sites in the myocardium. Am J Physiol Heart Circ Physiol. 2011;300:H1327-35. 
76. Piantadosi CA. Regulation of mitochondrial processes by protein S- nitrosylation. Biochim. Biophys Acta. 2012;1820:712-21.

77. Baba SP, Wetzelberger K, Hoetker JD, Bhatnagar A. Posttranslational glutathiolation of aldose reductase (AKR1B1): a possible mechanism of protein recovery from S-nitrosylation. Chem Biol Interact. 2009;178:250-8.

78. Lima B, Forrester MT, Hess DT, Stamler JS. S-nitrosylation in cardiovascular signaling. Circ Res. 2010;106:633-46.

79. Maron BA, Tang SS, Loscalzo J. S-nitrosothiols and the S-nitrosoproteome of the cardiovascular system. Antioxid Redox Signal. 2013;18:270-87.

80. Aracena-Parks P, Goonasekera SA, Gilman CP, Dirksen RT, Hidalgo C, Hamilton SL. Identification of cysteines involved in S-nitrosylation, S-glutathionylation, and oxidation to disulfides in ryanodine receptor type 1. J Biol Chem. 2006;281:40354-68.

81. Gonzalez DR, Treuer AV, Castellanos J, Dulce RA, Hare JM. Impaired S-nitrosylation of the ryanodine receptor caused by xanthine oxidase activity contributes to calcium leak in heart failure. J Biol Chem. 2010;285:28938-45.

82. Eu JP, Sun J, Xu L, Stamler JS, Meissner G. The skeletal muscle calcium release channel: coupled O2 sensor and NO signaling functions. Cell. 2000;102:499-509.

83. Adachi T, Weisbrod RM, Pimentel DR, Ying J, Sharov VS, Schöneich C, Cohen RA. Sglutathiolation by peroxynitrite activates SERCA during arterial relaxation by nitric oxide. Nat Med. 2004;10:1200-7.

84. Sun J, Picht E, Ginsburg KS, Bers DM, Steenbergen C, Murphy E. Hypercontractile female hearts exhibit increased S-nitrosylation of the L-type Ca2+ channel alpha1 subunit and reduced ischemia/reperfusion injury. Circ Res. 2006;98:403-11.

85. Yoshida T, Inoue R, Morii T, Takahashi N, Yamamoto S, Hara Y, Tominaga M, Shimizu S, Sato Y, Mori Y. Nitric oxide activates TRP channels by cysteine S-nitrosylation. Nat Chem Biol. 2006;2:596-607. 
86. Asada K, Kurokawa J, Furukawa T. Redox-and calmodulin-dependent S-nitrosylation of the KCNQ1 channel. J Biol Chem. 2009;284:6014-20.

87. Lu XM, Lu M, Tompkins RG, Fischman AJ. Site-specific detection of S-nitrosylated PKB alpha/Akt1 from rat soleus muscle using CapLC-Q-TOF(micro) mass spectrometry. J Mass Spectrom. 2005;40:1140-8.

88. Kwak YD, Ma T, Diao S, Zhang X, Chen Y, Hsu J, Lipton SA, Masliah E, Xu H, Liao FF. NO signaling and S-nitrosylation regulate PTEN inhibition in neurodegeneration. Mol Neurodegener. 2010;5:49.

89. Linares-Palomino J, Husainy MA, Lai VK, Dickenson JM, Galiñanes M. Selective blockade of protein kinase $\mathrm{B}$ protects the rat and human myocardium against ischaemic injury. $\mathrm{J}$ Physiol. 2010;588:2173-91.

90. Stamler JS. NO/redox disequilibrium in the failing heart and cardiovascular system. J Clin Invest. 2005;115:509-17.

91. Sun J, Steenbergen C, Murphy E. S-nitrosylation: NO-related redox signaling to protect against oxidative stress. Antioxid Redox Signal. 2006;8: 1693-705.

92. Hare JM, Stamler JS. NO/redox disequilibrium in the failing heart and cardiovascular system. J Clin Invest. 2005;115:509-17.

93. Vinten-Johansen J, Granfeldt A, Mykytenko J, Undyala VV, Dong Y, Przyklenk K. The multidimensional physiological responses to postconditioning. Antioxid Redox Signal. 2011;14:791-810.

94. Hausenloy DJ, Erik Bøtker H, Condorelli G, Ferdinandy P, Garcia-Dorado D, Heusch G, Lecour S, van Laake LW, Madonna R, Ruiz-Meana M, Schulz R, Sluijter JP, Yellon DM, Ovize M. Translating cardioprotection for patient benefit: position paper from the Working Group of Cellular Biology of the Heart of the European Society of Cardiology. Cardiovasc Res. 2013;98:7-27.

95. Penna C, Mancardi D, Rastaldo R, Pagliaro P. Cardioprotection: a radical view Free radicals in pre and postconditioning. Biochim Biophys Acta. 2009;1787:781-93. 
96. Burgoyne JR, Eaton P. Transnitrosylating nitric oxide species directly activate type I protein kinase A, providing a novel adenylate cyclase-independent cross-talk to beta-adrenergic-like signaling. J Biol Chem. 2009;284:29260-8.

97. Li XD, Cheng YT, Yang YJ, Meng XM, Zhao JL, Zhang HT, Wu YJ, You SJ, Wu YL. PKA-mediated eNOS phosphorylation in the protection of ischemic preconditioning against noreflow. Microvasc Res. 2012;84:44-54.

98. Edwards HV, Scott JD, Baillie GS. PKA phosphorylation of the small heat-shock protein Hsp20 enhances its cardioprotective effects. Biochem Soc Trans. 2012;40:210-4.

99. Yang C, Talukder MA, Varadharaj S, Velayutham M, Zweier JL. Early ischaemic preconditioning requires Akt- and PKA-mediated activation of eNOS via serine1176 phosphorylation. Cardiovasc Res. 2013;97:33-43.

100. Wetzelberger K, Baba SP, Thirunavukkarasu M, Ho YS, Maulik N, Barski OA, Conklin DJ, Bhatnagar A. Postischemic deactivation of cardiac aldose reductase: role of glutathione Stransferase $\mathrm{P}$ and glutaredoxin in regeneration of reduced thiols from sulfenic acids. J Biol Chem. 2010;285:26135-48.

101. Chen Y-R, Chen C-L, Pfeiffer DR, Zweier JL. Mitochondrial complex II in the postischemic heart: oxidative injury and the role of protein S-glutathionylation. J Biol Chem. 2007;282:32640-54.

102. Downey JM, Cohen MV. Reducing infarct size in the setting of acute myocardial infarction. Prog Cardiovasc Dis. 2006;48:363-71.

103. Perrelli MG, Pagliaro P, Penna C. Ischemia/reperfusion injury and cardioprotective mechanisms: Role of mitochondria and reactive oxygen species. World J Cardiol. 2011;3:186-200.

104. Strasen J, Ritter O. Role of nNOS in cardiac ischemia-reperfusion injury. Trends Cardiovasc Med. 2011;21:58-63.

105. Crisafulli A, Melis F, Tocco F, Pittau G, Lorrai L, Gori T, Mancardi D, Concu A, Pagliaro P. Delayed preconditioning-mimetic actions of exercise or nitroglycerin do not affect 
haemodynamics and exercise performance in trained or sedentary individuals. J Sports Sci. 2007;25:1393-401.

106. Vinten-Johansen J, Zhao ZQ, Jiang R, Zatta AJ. Myocardial protection in reperfusion with postconditioning. Expert Rev Cardiovasc Ther. 2005;3:1035-45.

107. Zhao ZQ, Vinten-Johansen J. Postconditioning: reduction of reperfusion-induced injury. Cardiovasc Res. 2006;70:200-11.

108. Yang X, Cohen MV, Downey JM. Mechanism of cardioprotection by early ischemic preconditioning. Cardiovasc Drugs Ther. 2010;24:225-34.

109. Ovize M, Baxter GF, Di Lisa F, Ferdinandy P, Garcia-Dorado D, Hausenloy DJ, Heusch G, Vinten-Johansen J, Yellon DM, Schulz R; Working Group of Cellular Biology of Heart of European Society of Cardiology. Postconditioning and protection from reperfusion injury: where do we stand? Position paper from the Working Group of Cellular Biology of the Heart of the European Society of Cardiology. Cardiovasc Res. 2010;87:406-23.

110. Siegfried MR, Erhardt J, Rider T, Ma XL, Lefer AM. Cardioprotection and attenuation of endothelial dysfunction by organic nitric oxide donors in myocardial ischemia-reperfusion. $\mathbf{J}$ Pharmacol Exp Ther. 1992;260:668-75.

111. Hill M, Takano H, Tang XL, Kodani E, Shirk G, Bolli R. Nitroglycerin induces late preconditioning against myocardial infarction in conscious rabbits despite development of nitrate tolerance. Circulation. 2001;104:694-9.

112. Penna C, Alloatti G, Cappello S, Gattullo D, Berta G, Mognetti B, Losano G, Pagliaro P. Platelet-activating factor induces cardioprotection in isolated rat heart akin to ischemic preconditioning: role of phosphoinositide 3-kinase and protein kinase $\mathrm{C}$ activation. Am $\mathrm{J}$ Physiol Heart Circ Physiol. 2005;288:H2512-20.

113. Iliodromitis EK, Gaitanaki C, Lazou A, Aggeli IK, Gizas V, Bofilis E, Zoga A, Beis I, Kremastinos DT. Differential activation of mitogen-activated protein kinases in ischemic and nitroglycerin-induced preconditioning. Basic Res Cardiol. 2006;101:327-35. 
114. Penna C, Settanni F, Tullio F, Trovato L, Pagliaro P, Alloatti G, Ghigo E, Granata R. GHreleasing hormone induces cardioprotection in isolated male rat heart via activation of RISK and SAFE pathways. Endocrinology. 2013;154:1624-35.

115. Perrelli MG, Tullio F, Angotti C, Cerra MC, Angelone T, Tota B, Alloatti G, Penna C, Pagliaro P. Catestatin reduces myocardial ischaemia/reperfusion injury: involvement of PI3K/Akt, PKCs, mitochondrial KATP channels and ROS signalling. Pflugers Arch. 2013;465:1031-40.

116. Hausenloy DJ, Yellon DM. Reperfusion injury salvage kinase signalling: taking a RISK for cardioprotection. Heart Fail Rev. 2007;12:217-34.

117. Cohen MV, Downey JM. Cardioprotection: spotlight on PKG. Br J Pharmacol. 2007; 152:833-4.

118. Hausenloy DJ, Yellon DM. Preconditioning and postconditioning: new strategies for cardioprotection. Diabetes Obes Metab. 2008;10:451-9.

119. Hausenloy DJ. Signalling pathways in ischaemic postconditioning. Thromb Haemost. 2009;101:626-34.

120. Hausenloy DJ, Ong SB, Yellon DM. The mitochondrial permeability transition pores as a target for preconditioning and postconditioning. Basic Res Cardiol. 2009;104:189-202.

121. Lecour S. Activation of the protective Survivor Activating Factor Enhancement (SAFE) pathway against reperfusion injury: Does it go beyond the RISK pathway? J Mol Cell Cardiol. 2009;47:32-40.

122. Lecour S. Multiple protective pathways against reperfusion injury: a SAFE path without Aktion? J Mol Cell Cardiol. 2009;46:607-9.

123. Mancardi D, Penna C, Merlino A, Del Soldato P, Wink DA, Pagliaro P. Physiological and pharmacological features of the novel gas-transmitter: hydrogen sulfide. Biochim Biophys Acta. 2009; 1787:864-72.

124. Ozcan S, Andrali SS, Cantrell JE. Modulation of transcription factor function by O-GlcNAc modification. Biochim Biophys Acta. 2010;1799:353-64. 
125. Feng X, Sun T, Bei Y, Ding S, Zheng W, Lu Y, Shen P. S-nitrosylation of ERK inhibits ERK phosphorylation and induces apoptosis. Sci Rep. 2013;3:1814.

126. Filice E, Angelone T, De Francesco EM, Pellegrino D, Maggiolini M, Cerra MC. Crucial role of phospholamban phosphorylation and S-nitrosylation in the negative lusitropism induced by 17ß-estradiol in the male rat heart. Cell Physiol Biochem. 2011;28:41-52.

127. Angelone T, Quintieri AM, Pasqua T, Gentile S, Tota B, Mahata SK, Cerra C. Phosphodiesterase type-2 and NO-dependent S-nitrosylation mediate the cardioinhibition of the antihypertensive catestatin. Am J Physiol Heart Circ Physiol. 2012;302:H431-42.

128. Inserte J, Ruiz-Meana M, Rodríguez-Sinovas A, Barba I, Garcia-Dorado D. Contribution of delayed intracellular $\mathrm{pH}$ recovery to ischemic postconditioning protection. Antioxid Redox Signal. 2011;14:923-39.

129. Sun J, Morgan M, Shen RF, Steenbergen C, Murphy E. Preconditioning results in Snitrosylation of proteins involved in regulation of mitochondrial energetic and calcium transport. Circ Res. 2007;101:1155-63.

130. Murphy E, Steenbergen C. Gender-based differences in mechanisms of protection in myocardial ischemia-reperfusion injury. Cardiovasc Res. 2007;75:478-86.

131. Sun J, Kohr MJ, Nguyen T, Aponte AM, Connelly PS, Esfahani SG, Gucek M, Daniels MP, Steenbergen C, Murphy E. Disruption of caveolae blocks ischemic preconditioning-mediated Snitrosylation of mitochondrial proteins. Antioxid Redox Signal. 2012;16:45-56.

132. Penna C, Bassino E, Alloatti G. Platelet activating factor: the good and the bad in the ischemic/reperfused heart. Exp Biol Med (Maywood). 2011;236:390-401.

133. Lotz C, Liem D, Ping P. New frontiers in myocardial protection: a systems biology approach. J Cardiovasc Pharmacol Ther. 2011;16:285-9.

134. Kohr MJ, Sun J, Aponte A, Wang G, Gucek M, Murphy E, Steenbergen C. Simultaneous measurement of protein oxidation and S-nitrosylation during preconditioning and ischemia/ reperfusion injury with resin-assisted capture. Circ Res. 2011;108:418-26. 
135. Okazaki T, Otani H, Shimazu T, Yoshioka K, Fujita M, Katano T, Ito S, Iwasaka T. Reversal of inducible nitric oxide synthase uncoupling unmasks tolerance to ischemia/reperfusion injury in the diabetic rat heart. J Mol Cell Cardiol. 2011;50:534-44.

136. Lin J, Steenbergen C, Murphy E, Sun J. Estrogen receptor-beta activation results in Snitrosylation of proteins involved in cardioprotection. Circulation. 2009;120:245-54.

137. Sun J. Protein S-nitrosylation: a role of nitric oxide signaling in cardiac ischemic preconditioning. Sheng Li Xue Bao. 2007;59:544-52.

138. Sawicki G, Jugdutt BI. Valsartan reverses post-translational modifications of the deltasubunit of ATP synthase during in vivo canine reperfused myocardial infarction. Proteomics. 2007;7:2100-10.

139. Murphy E, Steenbergen C. Cardioprotection in females: a role for nitric oxide and altered gene expression. Heart Fail Rev. 2007;12:293-300.

140. Asanuma H, Nakai K, Sanada S, Minamino T, Takashima S, Ogita H, Fujita M, Hirata A, Wakeno M, Takahama H, Kim J, Asakura M, Sakuma I, Kitabatake A, Hori M, Komamura K, Kitakaze M. S-nitrosylated and pegylated hemoglobin, a newly developed artificial oxygen carrier, exerts cardioprotection against ischemic hearts. J Mol Cell Cardiol. 2007;42:924-30.

141. Cai Z, Yan LJ. Protein Oxidative Modifications: Beneficial Roles in Disease and Health. J Biochem Pharmacol Res. 2013;1:15-26.

142. Murray CI, Chung HS, Uhrigshardt H, Van Eyk JE. Quantification of mitochondrial Snitrosylation by CysTMT ${ }^{6}$ switch assay. Methods Mol Biol. 2013;1005:169-79.

143. Murray CI, Van Eyk JE. A twist on quantification: measuring the site occupancy of Snitrosylation. Circ Res. 2012;111:1253-5.

144. Schulz R, Ferdinandy P. Does nitric oxide signaling differ in pre- and post-conditioning? Importance of S-nitrosylation vs. protein kinase G activation. Free Radic Biol Med. 2013;54:113-5. 
145. Kohr MJ, Aponte A, Sun J, Gucek M, Steenbergen C, Murphy E. Measurement of Snitrosylation occupancy in the myocardium with cysteine-reactive tandem mass tags: short communication. Circ Res. 2012;111:1308-12.

146. Hidalgo C, Donoso P, Carrasco MA. The ryanodine receptors $\mathrm{Ca} 2+$ release channels: cellular redox sensors? IUBMB Life. 2005;57:315-22.

147. Lin YF, Raab-Graham K, Jan YN, Jan LY. NO stimulation of ATP-sensitive potassium channels: Involvement of Ras/mitogen-activated protein kinase pathway and contribution to neuroprotection. Proc Natl Acad Sci USA. 2004;101:7799-804.

148. Andoh T, Lee SY, Chiueh CC. Preconditioning regulation of bcl-2 and p66shc by human NOS1 enhances tolerance to oxidative stress. FASEB J. 2000;14:2144-6.

149. Penna C, Perrelli MG, Tullio F, Angotti C, Camporeale A, Poli V, Pagliaro P. Diazoxide postconditioning induces mitochondrial protein S-Nitrosylation and a redox-sensitive mitochondrial phosphorylation/translocation of RISK elements: no role for SAFE. Basic Res Cardiol. 2013;108:371.

150. Methner C, Lukowski R, Grube K, Loga F, Smith RA, Murphy MP, Hofmann F, Krieg T. Protection through postconditioning or a mitochondria-targeted S-nitrosothiol is unaffected by cardiomyocyte-selective ablation of protein kinase G. Basic Res Cardiol. 2013;108:337.

151. Nadtochiy SM, Burwell LS, Brookes PS. Cardioprotection and mitochondrial S-nitrosation: effects of S-nitroso-2-mercaptopropionyl glycine (SNO-MPG) in cardiac ischemia-reperfusion injury. J Mol Cell Cardiol. 2007;42:812-25.

152. Prime TA, Blaikie FH, Evans C, Nadtochiy SM, James AM, Dahm CC, Vitturi DA, Patel RP, Hiley CR, Abakumova I, Requejo R, Chouchani ET, Hurd TR, Garvey JF, Taylor CT, Brookes PS, Smith RA, Murphy MP. A mitochondria-targeted S-nitrosothiol modulates respiration, nitrosates thiols, and protects against ischemia-reperfusion injury. Proc Natl Acad Sci USA 2009;106:10764-9. 
153. Chouchani ET, Hurd TR, Nadtochiy SM, Brookes PS, Fearnley IM, Lilley KS, Smith RA, Murphy MP. Identification of S-nitrosated mitochondrial proteins by S-nitrosothiol difference in gel electrophoresis (SNO-DIGE): implications for the regulation of mitochondrial function by reversible S-nitrosation. Biochem J. 2010;430:49-59.

154. Sun J, Aponte AM, Kohr MJ, Tong G, Steenbergen C, Murphy E. Essential role of nitric oxide in acute ischemic preconditioning: S-nitros(yl)ation versus sGC/cGMP/PKG signaling? Free Radic Biol Med. 2013;54:105-12.

155. Barua A, Standen NB, Galiñanes M. Dual role of nNOS in ischemic injury and preconditioning. BMC Physiol. 2010;10:15.

156. Cohen MV, Yang X-M, Downey JM. Nitric oxide is a preconditioning mimetic and cardioprotectant and is the basis of many available infarct sparing strategies. Cardiovasc Res. 2006;70:231-9.

157. Guo Y, Li Q, Wu W-J, Tan W, Zhu X, Mu J, Bolli R. Endothelial nitric oxide synthase is not necessary for the early phase of ischemic preconditioning in the mouse. J Mol Cell Cardiol. 2008;44:496-501.

158. Oldenburg O, Qin Q, Krieg T, Yang X-M, Philipp S, Critz SD, Cohen MV, Downey JM. Bradykinin induces mitochondrial ROS generation via NO, cGMP, PKG, and mitoKATP channel opening and leads to cardioprotection. Am J Physiol. 2004;286:H468-76.

159. Bell RM, Yellon DM. The contribution of endothelial nitric oxide synthase to early ischaemic preconditioning: the lowering of the preconditioning threshold. An investigation in eNOS knockout mice. Cardiovasc Res. 2001;52:274-80.

160. Shiva S, Sack MN, Greer JJ, Duranski M, Ringwood LA, Burwell L, Wang X, MacArthur PH, Shoja A, Raghavachari N, Calvert JW, Brookes PS, Lefer DJ, Gladwin MT. Nitrite augments tolerance to ischemia/reperfusion injury via the modulation of mitochondrial electron transfer. $\mathbf{J}$ Exp Med. 2007;204:2089-102. 
161. González DR, Fernández IC, Ordenes PP, Treuer AV, Eller G, Boric MP. Differential role of S-nitrosylation and the NO-cGMP-PKG pathway in cardiac contractility. Nitric Oxide. 2008;18:157-67.

162. Garlid KD, Costa AD, Quinlan CL, Pierre SV, Dos Santos P. Cardioprotective signaling to mitochondria. J Mol Cell Cardiol. 2009;46:858-66.

163. Quinlan CL, Costa AD, Costa CL, Pierre SV, Dos Santos P, Garlid KD. Conditioning the heart induces formation of signalosomes that interact with mitochondria to open mitoKATP channels. Am J Physiol Heart Circ Physiol. 2008;295:H953-H961.

164. Tang Z, Scherer PE, Okamoto T, Song K, Chu C, Kohtz DS,Nishimoto I, Lodish HF, Lisanti MP. Molecular cloning of caveolin-3, a novel member of the caveolin gene family expressed predominantly in muscle. J Biol Chem. 1996;271:2255-61.

165. Penna C, Perrelli MG, Pagliaro P. Mitochondrial pathways, permeabilità transition pore, and redox signaling in cardioprotection: therapeutic implications. Antioxid Redox Signal. 2013;18:55699.

166. Murphy E, Steenbergen C. Preconditioning: the mitochondrial connection. Annu Rev Physiol. 2007;69:51-67.

167. Krieg T, Liu Y, Rütz T, Methner C, Yang XM, Dost T, Felix SB, Stasch JP, Cohen MV, Downey JM. BAY 58-2667, a nitric oxide-independent guanylyl cyclase activator, pharmacologically post-conditions rabbit and rat hearts. Eur Heart J. 2009;30:1607-13.

168. Salloum FN, Das A, Samidurai A, Hoke NN, Chau VQ, Ockaili RA, Stasch JP, Kukreja RC. Cinaciguat, a novel activator of soluble guanylate cyclase, protects against ischemia/reperfusion injury: role of hydrogen sulfide. Am J Physiol Heart Circ Physiol. 2012;302:H1347-54.

169. Radovits T, Korkmaz S, Miesel-Gröschel C, Seidel B, Stasch JP, Merkely B, Karck M, Szabó G. Pre-conditioning with the soluble guanylate cyclase activator Cinaciguat reduces ischaemia-reperfusion injury after cardiopulmonary bypass. Eur J Cardiothorac Surg. 2011;39:24855. 
170. Schulman IH, Hare JM. Regulation of cardiovascular cellular processes by S-nitrosylation. Biochim Biophys Acta. 2012;1820:752-62.

171. Steinberg SF. Oxidative stress and sarcomeric proteins. Circ Res. 2013;112:393-405.

172. Gonzalez DR, Treuer A, Sun QA, Stamler JS, Hare JM. S-Nitrosylation of cardiac ion channels. J Cardiovasc Pharmacol. 2009;54:188-95.

173. Garcia-Dorado D, Ruiz-Meana M, Inserte J, Rodriguez-Sinovas A, Piper HM.Calciummediated cell death during myocardial reperfusion. Cardiovasc Res. 2012;94:168-80.

174. Zima AV, Blatter LA. Redox regulation of cardiac calcium channels and transporters. Cardiovasc Res. 2006;71:310-21.

175. Eu JP, Hare JM, Hess DT, Skaf M, Sun J, Cardenas-Navina I, Sun QA, Dewhirst M, Meissner G, Stamler JS. Concerted regulation of skeletal muscle contractility by oxygen tension and endogenous nitric oxide. Proc Natl Acad Sci U S A. 2003;100:15229-34.

176. Eu JP, Sun J, Xu L, Stamler JS, Meissner G. The skeletal muscle calcium release channel: coupled O2 sensor and NO signaling functions. Cell. 2000;102:499-509.

177. Xu L, Eu JP, Meissner G, Stamler JS. Activation of the cardiac calcium release channel (ryanodine receptor) by poly-S-nitrosylation. Science. 1998;279:234-37.

178. Suko J, Drobny H, Hellmann G. Activation and inhibition of purified skeletal muscle calcium release channel by NO donors in single channel current recordings. Biochimica et Biophysica Acta. 1999;1451:271-287.

179. Cheong E, Tumbev V, Abramson J, Salama G, Stoyanovsky DA. Nitroxyl triggers Ca2+ release from skeletal and cardiac sarcoplasmic reticulum by oxidizing ryanodine receptors. Cell Calcium. 2005;37:87-96.

180. Cheong E, Tumbev V, Stoyanovsky D, Salama G. Effects of pO(2) on the activation of skeletal muscle ryanodine receptors by NO, A cautionary note. Cell Calcium. 2005;38:481-488. 
181. Hart JD, Dulhunty AF. Nitric oxide activates or inhibits skeletal muscle ryanodine receptors depending on its concentration, membrane potential and ligand binding. The Journal of Membrane Biology. 2000; 173:227-336. [PubMed: 10667918]

182. Sun J, Yamaguchi N, Xu L, Eu JP, Stamler JS, Meissner G. Regulation of the cardiac muscle ryanodine receptor by $\mathrm{O} 2$ tension and S-nitrosoglutathione. Biochemistry. 2008; 47:1398590.

183. Tocchetti CG, Wang W, Froehlich JP, Huke S, Aon MA, Wilson GM, et al. Nitroxyl improves cellular heart function by directly enhancing cardiac sarcoplasmic reticulum $\mathrm{Ca} 2+$ cycling. Circulation Research. 2007;100:96-104.

184. Pagliaro P, Mancardi D, Rastaldo R, Penna C, Gattullo D, Miranda KM, Feelisch M, Wink DA, Kass DA, Paolocci N. Nitroxyl affords thiol-sensitive myocardial protective effects akin to early preconditioning. Free Radic Biol Med. 2003;34:33-43.

185. Campbell DL, Stamler JS, Strauss HC. Redox modulation of L-type calcium channels in ferret ventricular myocytes. Dual mechanism regulation by nitric oxide and S-nitrosothiols. J Gen Physiol. 1996;108:277-93.

186. Hu H, Chiamvimonvat N, Yamagishi T, Marban E. Direct inhibition of expressed cardiac Ltype Ca2+ channels by S-nitrosothiol nitric oxide donors. Circ Res. 1997;81:742-52.

187. Poteser M, Romanin C, Schreibmayer W, Mayer B, Groschner K. S-nitrosation controls gating and conductance of the alpha 1 subunit of class $\mathrm{C}$ L-type $\mathrm{Ca}(2+)$ channels. J Biol Chem. 2001;276:14797-803.

188. Leary PJ, Rajasekaran S, Morrison RR, Tuomanen EI, Chin TK, Hofmann PA. A cardioprotective role for platelet-activating factor through NOS-dependent S-nitrosylation. Am $\mathbf{J}$ Physiol Heart Circ Physiol. 2008;294:H2775-84.

189. del Monte F, Lebeche D, Guerrero JL, Tsuji T, Doye AA, Gwathmey JK, Hajjar RJ. Abrogation of ventricular arrhythmias in a model of ischemia and reperfusion by targeting myocardial calcium cycling. Proc Natl Acad Sci USA. 2004;101:5622-7. 
190. Zucchi R, Ronca F, Ronca-Testoni S. Modulation of sarcoplasmic reticulum function: a new strategy in cardioprotection? Pharmacol Ther. 2001;89:47-65.

191. Foster DB, O'Rourke B, Van Eyk JE. What can mitochondrial proteomics tell us about cardioprotection afforded by preconditioning? Expert Rev Proteomics. 2008;5:633-6.

192. Penna C, Pagliaro P, Rastaldo R, Di Pancrazio F, Lippe G, Gattullo D, Mancardi D, Samaja M, Losano G, Mavelli I. F0F1 ATP synthase activity is differently modulated by coronary reactive hyperemia before and after ischemic preconditioning in the goat. Am J Physiol Heart Circ Physiol. 2004;287:H2192-200.

193. Galkin A, Moncada S. S-nitrosation of mitochondrial complex I depends on its structural conformation. J Biol Chem. 2007;282:37448-53.

194. Heusch G, Boengler K, Schulz R. Inhibition of mitochondrial permeability transition pore opening: the Holy Grail of cardioprotection. Basic Res Cardiol. 2010;105:151-4.

195. Nguyen TT, Stevens MV, Kohr M, Steenbergen C, Sack MN, Murphy E. Cysteine 203 of cyclophilin D is critical for cyclophilin D activation of the mitochondrial permeability transition pore. J Biol Chem. 2011;286:40184-92.

196. Martin C, Schulz R, Post H, Boengler K, Kelm M, Kleinbongard P, Gres P, Skyschally A, Konietzka I, Heusch G. Microdialysis-based analysis of interstitial NO in situ: NO synthaseindependent NO formation during myocardial ischemia. Cardiovasc Res. 2007;74:46-55.

197. Granfeldt A, Lefer DJ, Vinten-Johansen J. Protective ischemia in patients: preconditioning and postconditioning. Cardiovasc Res. 2009;83: 234-46.

198. Penna C, Rastaldo R, Mancardi D, Raimondo S, Cappello S, Gattullo D, Losano G, Pagliaro P. Post-conditioning induced cardioprotection requires signaling through a redox-sensitive mechanism, mitochondrial ATP-sensitive $\mathrm{K}+$ channel and protein kinase $\mathrm{C}$ activation. Basic Res Cardiol. 101:180-189, 2006. 
199. Zatta AJ, Kin H, Lee G, Wang N, Jiang R, Lust R, Reeves JG, Mykytenko J, Guyton RA, Zhao ZQ, Vinten-Johansen J. Infarct-sparing effect of myocardial postconditioning is dependent on protein kinase C signalling. Cardiovasc Res. 2006;70:315-24.

200. Kuno A, Critz SD, Cohen MV, Downey JM. Nicorandil opens mitochondrial K(ATP) channels not only directly but also through a NO-PKG-dependent pathway. Basic Res Cardiol. 2007;102:73-9.

201. Foster DB, Ho AS, Rucker J, Garlid AO, Chen L, Sidor A, Garlid KD, O'Rourke B. Mitochondrial ROMK channel is a molecular component of mitoK(ATP). Circ Res 2012:111:44654.

202. Saini HK, Machackova J, Dhalla NS. Role of reactive oxygen species in ischemic preconditioning of subcellular organelles in the heart. Antioxid Redox Signal. 2004;6:393-404.

203. Boengler K, Konietzka I, Buechert A, Heinen Y, Garcia-Dorado D, Heusch G, Schulz R. Loss of ischemic preconditioning's cardioprotection in aged mouse hearts is associated with reduced gap junctional and mitochondrial levels of connexin 43. Am J Physiol Heart Circ Physiol. 2007;292:H1764-H1769.

204. Rodriguez-Sinovas A, Boengler K, Cabestrero A, Gres P, Morente M, Ruiz-Meana M, Konietzka I, Miró E, Totzeck A, Heusch G, Schulz R, Garcia-Dorado D. Translocation of connexin 43 to the inner mitochondrial membrane of cardiomyocytes through the heat shock protein 90dependent TOM pathway and its importance for cardioprotection. Circ Res. 2006;99:93-101.

205. Sánchez JA, Rodríguez-Sinovas A, Barba I, Miró-Casas E, Fernández-Sanz C, Ruiz-Meana M, Alburquerque-Béjar JJ, García-Dorado D. Activation of RISK and SAFE pathways is not involved in the effects of $\mathrm{Cx} 43$ deficiency on tolerance to ischemia-reperfusion injury and preconditioning protection. Basic Res Cardiol. 2013;108:351.

206. Chouchani ET, Methner C, Nadtochiy SM, Logan A, Pell VR, Ding S, James AM, Cochemé HM, Reinhold J, Lilley KS, Partridge L, Fearnley IM, Robinson AJ, Hartley RC, Smith RA, Krieg 
T, Brookes PS, Murphy MP. Cardioprotection by S-nitrosation of a cysteine switch on mitochondrial complex I. Nat Med. 2013;19:753-9.

207. James AM, Sharpley MS, Manas AR, Frerman FE, Hirst J, Smith RA, Murphy MP. Interaction of the mitochondria-targeted antioxidant MitoQ with phospholipid bilayers and ubiquinone oxidoreductases. J Biol Chem. 2007;282:14708-18.

208. Penna C, Cappello S, Mancardi D, Raimondo S, Rastaldo R, Gattullo D, Losano G, Pagliaro P. Post-conditioning reduces infarct size in the isolated rat heart: role of coronary flow and pressure and the nitric oxide/cGMP pathway. Basic Res Cardiol. 2006;101:168-79.

209. Inserte J, Barba I, Poncelas-Nozal M, Hernando V, Agulló L, Ruiz-Meana M, GarciaDorado D. cGMP/PKG pathway mediates myocardial postconditioning protection in rat hearts by delaying normalization of intracellular acidosis during reperfusion. $\mathrm{J}$ Mol Cell Cardiol. 2011;50:903-9.

210. Penna C, Mancardi D, Raimondo S, Geuna S, Pagliaro P. The paradigm of postconditioning to protect the heart. J Cell Mol Med. 2008;12:435-58.

211. Iliodromitis EK, Andreadou I, Prokovas E, Zoga A, Farmakis D, Fotopoulou T, Ioannidis K, Paraskevaidis IA, Kremastinos DT. Simvastatin in contrast to postconditioning reduces infarct size in hyperlipidemic rabbits: possible role of oxidative/nitrosative stress attenuation. Basic Res Cardiol. 2010;105:193-203.

212. Fan Q, Yang XC, Liu Y, Wang LF, Liu SH, Ge YG, Chen ML, Wang W, Zhang LK, Irwin MG, Xia Z. Postconditioning attenuates myocardial injury by reducing nitro oxidative stress in vivo in rats and in humans. Clin Sci (Lond). 2010; 120:251-261. 


\section{Legends}

\section{Figure 1. Nitric Oxide Based Signaling.}

Many of the effects mediated by nitric oxide (NO) are due to production of cyclic guanosine monophosphate (cGMP) or posttranslational protein modifications, such as S-nitrosylation (SNO). These processes are deactivated by cGMP-phosphodiesterase (PDE), which hydrolyzes cGMP to guanosine monophosphate (GMP), and by de-nitrosylation, respectively.

GTP: guanosine triphosphate; Protein-Cys-SH: protein cysteine thiols; sGC: soluble guanylyl cyclase.

\section{Figure 2. Cardioprotective Pathways Activated by Preconditioning and Postconditioning.}

Preconditioning and postconditioning, obtained with brief intermittent ischemia or with pharmacological agents, allow the heart to activate cardioprotective signal pathways, including the so-called cGMP/PKG, RISK (Reperfusion Injury Salvage Kinase) and SAFE (Survival Activating Factor Enhancement) pathways; three pathways which interact to convey the protective stimulus from the cell surface to the mitochondria, where many of the pro-survival signals appear to converge in reperfusion phase. These pathways comprise the involvement of NOS and the production of nitric oxide (NO) and, in fact, several mitochondrial proteins are nitrosylated (SNO). AKT: protein kinase B; cGMP: cyclic guanosine monophosphate; eNOS: endothelial nitric oxide synthase; ERK: p42/p44 extracellular regulated kinase; GC: guanylyl cyclase; GPCR: G-protein coupled receptor; GSK3ß: glycogen synthase kinase 3 beta; gp130: ligand-binding molecule; IL-6: interleukin 6; JAK: Januse kinase; MEK: mitogen extra regulated kinase; mKATP mitochondrial $\mathrm{K}_{\text {ATP }}$ channels; mPTP: mitochondrial permeability transition pore; PI3K: phosphatidyl inositol 3 kinase; PKG: protein kinase G; PKCE: protein kinase C epsilon; STAT3: Signal transducer and activator of transcription 3; TNF: Tumor necrosis factor; TNFR2: Tumor necrosis factor receptor 2. 
S-nitrosylated proteins produced by the PreC maneuvers can contribute to cardioprotection influencing mechanisms for calcium control and inhibiting opening of mitochondrial permeability transition pore (mPTP).

During PreC several proteins are nitrosylated (SNO). These include L-type calcium channels sarcoplasmatic reticulum pump $2\left(\mathrm{SERCA}_{2}\right)$ which are responsible for a decreased of $\mathrm{Ca}^{++}$loading and consequent reduced open probability of $\mathrm{mPTP}$. Moreover the inhibition of $\mathrm{F}_{0} \mathrm{~F}_{1}$-ATPase reduces indirectly the opening probability of mPTP. In fact $\mathrm{F}_{0} \mathrm{~F}_{1}$-ATPase inhibition preserves ATP levels and reduces the mitochondrial potential, thereby reducing the driving force for $\mathrm{Ca}^{++}$uptake into the mitochondrial matrix. PreC also increases the S-nitrosylation of different proteins involved in mitochondrial metabolism (i.e. Alpha-ketoglutarate dehydrogenase ( $\alpha \mathrm{KGDH})$, mitochondrial respiratory complex I).

ANT: adenine nucleotide translocator; CyPD: cyclophilin D; IMM: inner mitochondrial membrane; OMM: outer mitochondrial membrane; ROS: reactive oxygen species; VDAC: voltage dependent anion channel.

\section{Figure 4. Control of $\mathrm{Ca}^{++}$Handling by S-Nitrosylation.}

SNO affects the activity of proteins involved in the mechanisms of $\mathrm{Ca}^{++}$handling. The cardiac form of the tetrameric ryanodine receptor $/ \mathrm{Ca}^{++}$release channel (RyR2) colocalizes with neuronal nitric oxide synthase (nNOS) in the sarcoplasmic reticulum membrane. S-nitrosylation of RyR2 (RyRSNO) may affect $\mathrm{Ca}^{++}$release; however whether RyR-SNO increases or decreases $\mathrm{Ca}^{++}$release is not clear in cardiac muscle (question mark). The sarcoplasmic reticulum $\mathrm{Ca}^{++}$ATPase pump $\left(\mathrm{SERCA}_{2}\right)$ is also S-nitrosylated and is associated to infarct size reduction as well as to improved cardiac function following myocardial ischemia. While S-nitrosilatyon increases activity of $\mathrm{SERCA}_{2}$, it induces the inhibition of L-type calcium channels colocalized on sarcolemma with endothelial NOS (eNOS). 
Figure 5. Protein S-Nitrosylation During Intermittent Reperfusion in Postconditioning.

Intermittent reoxygenation, and acidosis are conditions that may allow nitric oxide (NO) production and S-Nitrosylation (SNO) of mitochondrial proteins, while limiting 3-nitrotyrosine (P-Tyr-3-NO $\left.\mathrm{NO}_{2}\right)$ formation. Superoxide dismutase (SOD) downregulation may limit the process of denitrosylation. ANT: adenine nucleotide translocator; $\mathrm{N}_{2} \mathrm{O}_{3}$ : dinitrogen trioxide; NOSs: nitric oxide synthases; $\mathrm{O}_{2}{ }^{-}$: superoxide anion; $\mathrm{ONOO}^{-}$: peroxynitrite; VDAC: voltage dependent anion channel. 


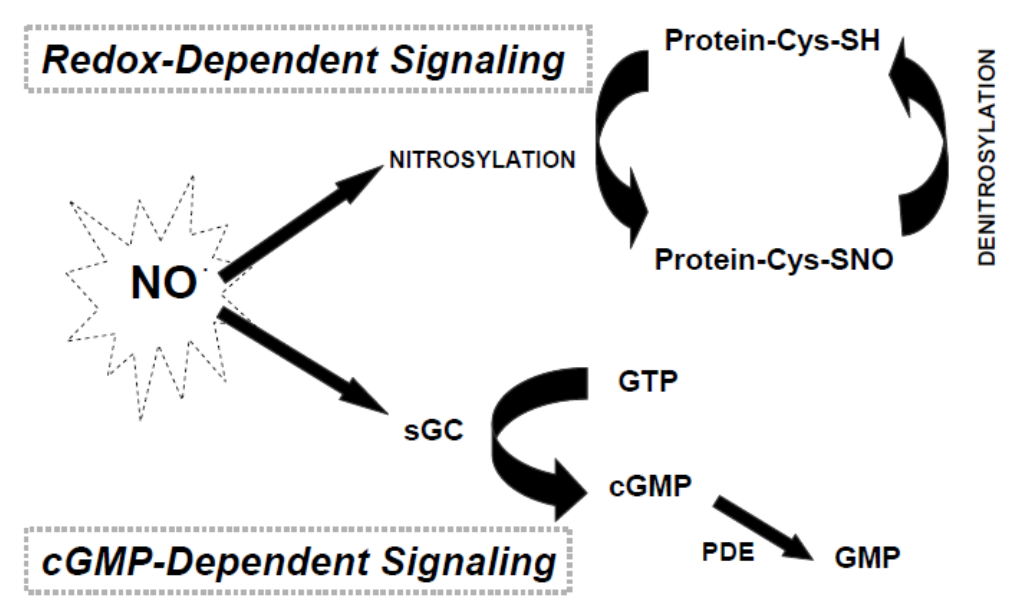

Fig 1

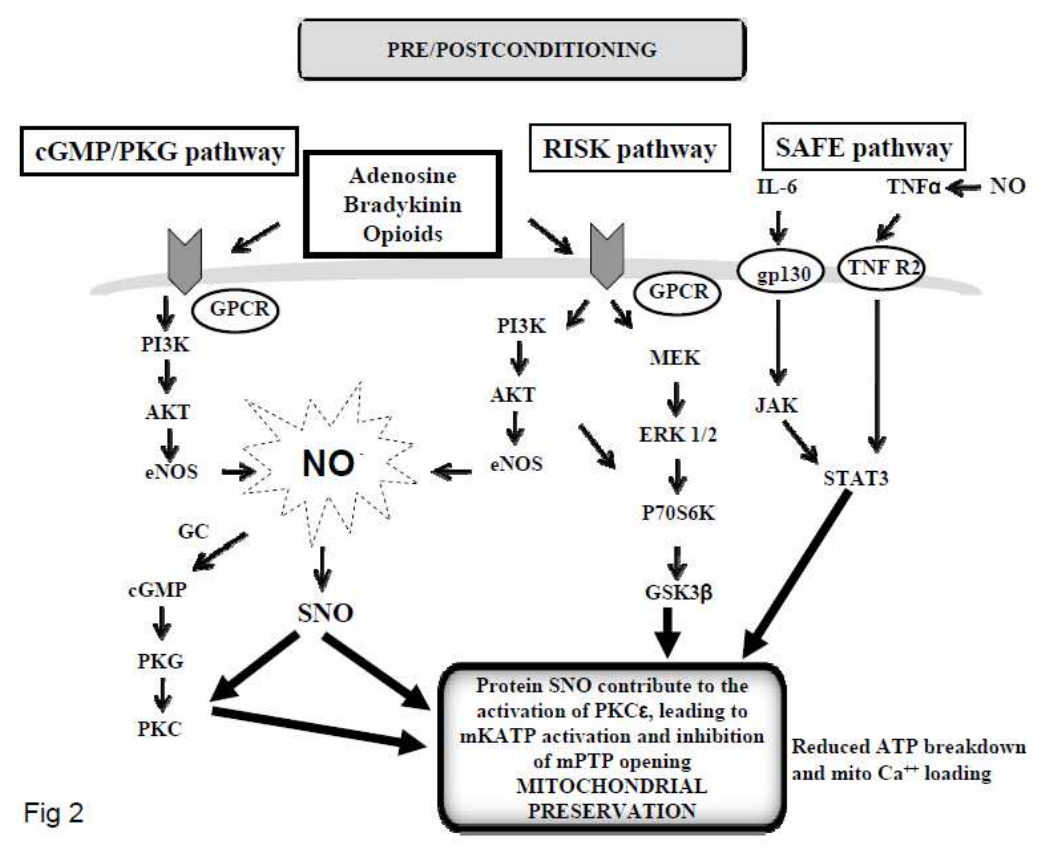



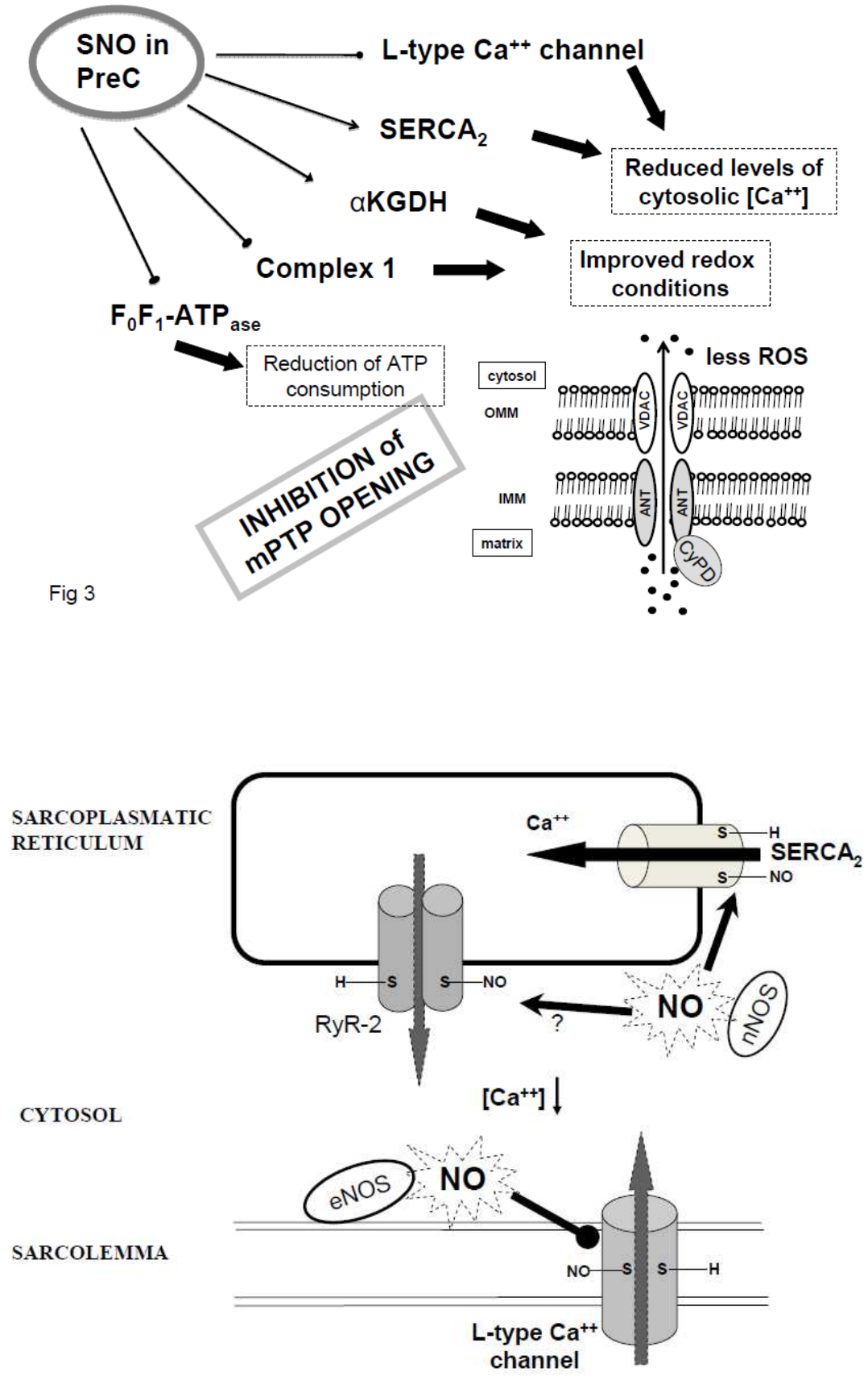

Fig 4 


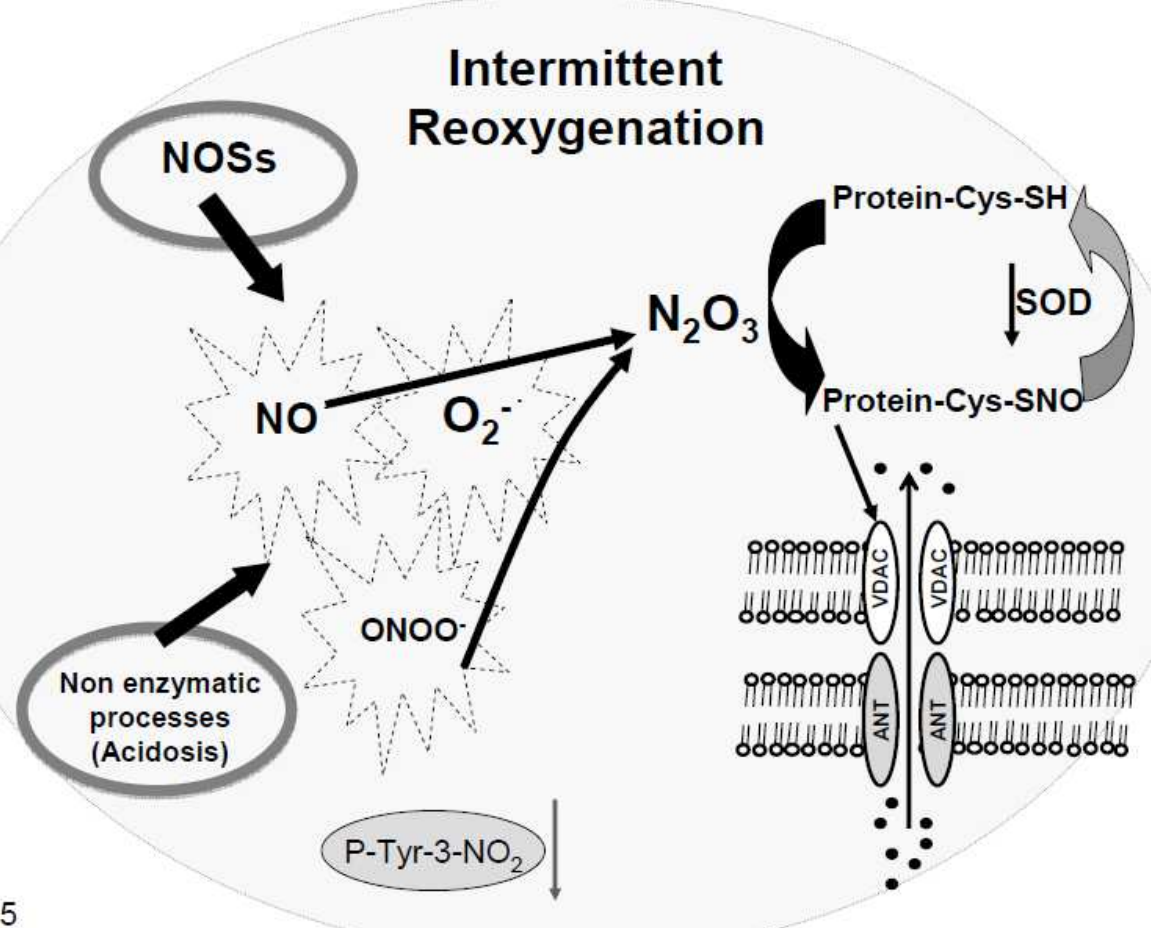

Fig 5 
Table 1, S-nitrosylated proteins reported to be subjected to S-nitrosylation and involved in cardioprotection.

\begin{tabular}{|l|l|}
\hline Plasma membrane and cytosolic proteins & References \\
\hline Caveolin-3* & 131 \\
\hline Cyclooxygenase $2^{*}$ & 34 \\
\hline L-type calcium channel & 129 \\
\hline p42/p44 extracellular signal-regulated kinase 1/2* & 125 \\
\hline $\begin{array}{l}\text { Phosphatase and tensin homologue deleted on } \\
\text { chromosome } 10^{*}\end{array}$ & 88 \\
\hline Protein Kinase A* & \\
\hline Protein Kinase B/Akt* & 98 \\
\hline Protein Kinase C* & 87 \\
\hline Protein Kinase G* & 91 \\
\hline Mitochondrial proteins & $49,150,161,208,209$ \\
\hline Aconitase & \\
\hline Alpha-ketoglutarate dehydrogenase & $65,153,192$ \\
\hline Complex I & 65,192 \\
\hline Cyclophillin D & 76,151 \\
\hline Electron transfer flavoprotein $\alpha, \beta$ & 195 \\
\hline Fo $_{0}$ ATPase & 47 \\
\hline Glycogen-phosphorylase & 138,192 \\
\hline Voltage dependent anion channel & 65,192 \\
\hline Sarcoplasmatic proteins & 149 \\
\hline Phospholamban & \\
\hline Ryanodine receptors & $9,126,127$ \\
\hline Sarcoplasmatic reticulum pump 2 & $80,81,175-177$ \\
\hline
\end{tabular}

Proteins are subdivided on the basis of their sub-cellular localization. *These proteins may have multiple localizations on the membrane and within cellular organelles, depending on a variety of conditions. 